\title{
norden
}

Nordic Council of Ministers

Ved Stranden 18

DK-1061 Copenhagen $\mathrm{K}$

www.norden.org

NORDISKE ARBEJDSPAPIRER

NORDIC WORKING PAPERS

\section{Suspected endocrine disrupting substances}

How well does the OECD Conceptual Framework capture suspect-

ed endocrine disrupting substances

Pär Hallgren, SWECO

NA2013:921

http://dx.doi.org/10.6027/NA2013-921

This working paper has been published with financial support from the Nordic Council of Ministers. However, the contents of this working paper do not necessarily reflect the views, policies or recommendations of the Nordic Council of Ministers. 


\section{How well does the OECD Conceptual Framework capture suspected endocrine disrupting substances}

\section{Contents}

Preface . .2

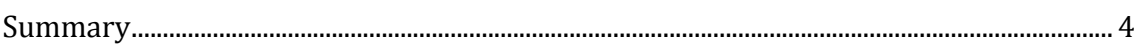

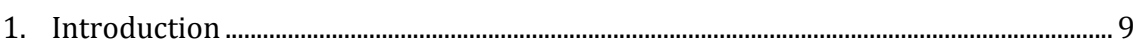

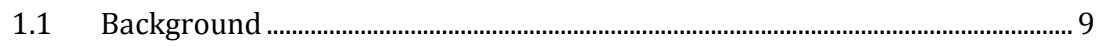

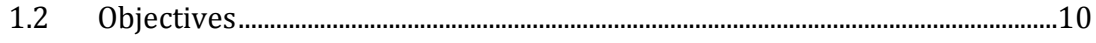

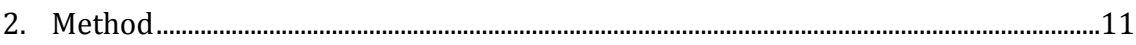

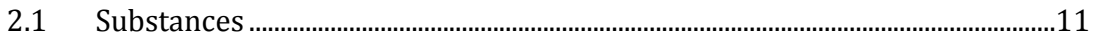

$2.2 \quad$ Literature search ...............................................................................................12

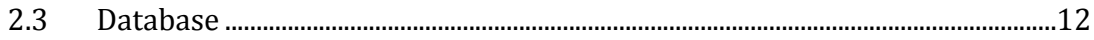

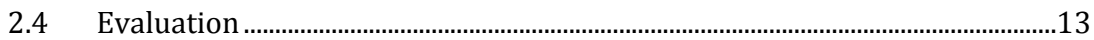

$2.5 \quad$ Limitations and definitions .............................................................................14

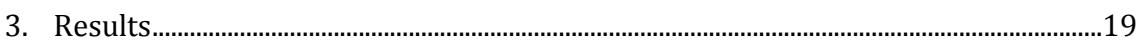

3.1 Literature search ..................................................................................................19

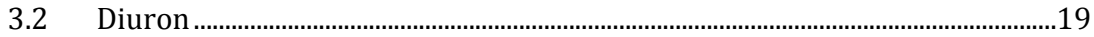

In vitro studies.........................................................................................................20

Mammalian toxicology ........................................................................................21

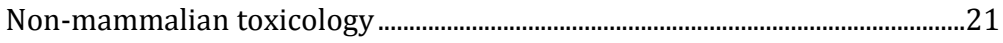

3.3 Piperonyl butoxide ....................................................................................................26

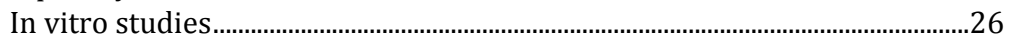

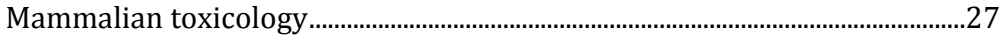

Non-mammalian toxicology ................................................................................28

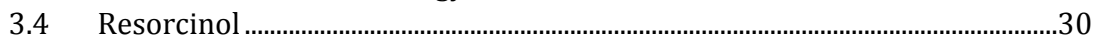

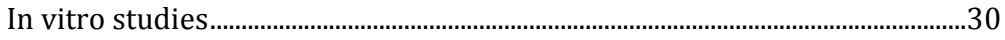

Mammalian toxicology ...............................................................................................3

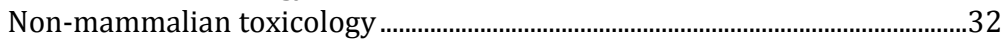

4. Discussion ....................................................................................................................................35

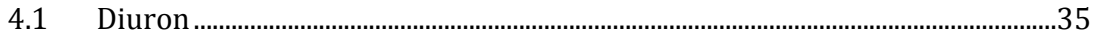

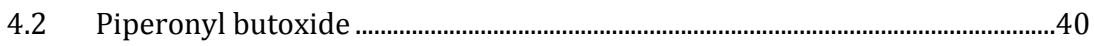

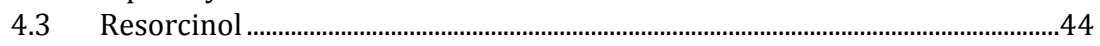

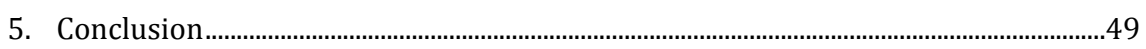

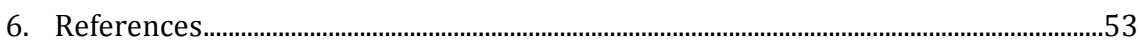

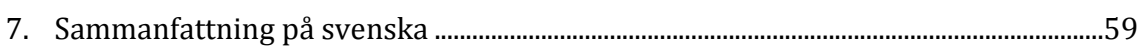




\section{Preface}

There is a need to develop criteria to identify endocrine disrupting substances for regulatory action within existing regulatory frameworks. At the same time there are substantial knowledge gaps, e.g. concerning mode-of-action, low-dose effects, and the role of homeostasis for endocrine disrupting substances. By compiling information on suspected endocrine disruptors and evaluating the usability of this information from both a risk assessment and regulatory perspective we can improve the foundation for the development of criteria to identify endocrine disruptors in a proactive way, i.e. before we see the effects in epidemiological studies in the population or the environment

The aim of the project was to use available information from scientific publications on three suspected endocrine disruptors to evaluate how non-standard test methods compared to test guidelines included in the OECD conceptual framework manage to identify endocrine disruptors.

The results give a basis for how to improve our continued work with risk assessment and regulation of endocrine disruptors (test methods used, research needs, improvement of regulation etc.) ${ }^{1}$.

The project has been funded by the Nordic Council of Ministers for the environment through the Nordic Chemicals Group (NKG). The overall goal for the group is to minimize negative health and environmental effects from chemicals in products, emissions and waste.

The publication has been written by Pär Hallgren, SWECO. The project was managed by Ing-Marie Olsson and Yvonne Andersson, the Swedish Chemicals Agency. The Nordic Risk Assessment Group (NORAP), a project group under the NKG, is responsible for this report and the publication has been produced and published by the Nordic Council of Ministers.

${ }^{1}$ Additional information can be found in another study on three known endocrine disruptors - a report in Swedish (PM 15/12, summary also in English) is available at

http://www.kemi.se/Documents/Publikationer/Trycksaker/PM/PM 1512 karakt hormon.pdf. 


\section{Abbreviations}

$\begin{array}{ll}\text { AR } & \text { Androgen Receptor } \\ \text { CF } & \text { OECDs Conceptual Framework for Testing and } \\ & \text { Assessment of Endocrine Disrupters } \\ \text { CYP } & \text { Cytochrome P450 } \\ \text { EATS } & \begin{array}{l}\text { Estrogen/ Androgen/ Thyroid/ Steroidogenesis } \\ \text { - modalities }\end{array} \\ \text { EC50 } & \text { 50\% of maximum Effect Concentration } \\ \text { ED } & \text { Endocrine Disruption } \\ \text { ER } & \text { Estrogen Receptor } \\ \text { LO(A)EC } & \text { Lowest Observed Adverse Effect Concentration } \\ \text { LO(A)ED } & \text { Lowest Observed Adverse Effect Dose } \\ \text { NO(A)EC } & \text { No Observed Adverse Effect Concentration } \\ \text { NO(A)ED } & \text { No Observed Adverse Effect Dose } \\ \text { NORAP } & \text { Nordic Risk Assessment Group } \\ \text { NR } & \text { Nuclear Receptor } \\ \text { OECD } & \text { Organisation for Economic Co-operation and } \\ & \text { Development } \\ \text { PPARs } & \text { Peroxisome Proliferator-Activated Receptors } \\ \text { REACH } & \text { Registration Evaluation and Authorization of Chemicals } \\ \text { TG } & \text { Test Guideline } \\ \text { TH } & \text { Thyroid Hormone } \\ \text { TSH } & \text { Thyroid-Stimulating Hormone } \\ \text { VTG } & \text { Vitellogenin } \\ \text { YAS } & \text { Yeast Androgen Screen } \\ \text { YES } & \text { Yeast Estrogen Screen }\end{array}$




\section{Summary}

Chemicals with endocrine disrupting effects (EDCs) need to be identified in order to comply with $\mathrm{REACH}^{2}$ and other relevant legislations (BPR ${ }^{3}$ and $\mathrm{PPP}^{4}$ ). Requirements for testing of chemicals are included or connected to these legislations and the test methods are specified in the regulations or the test method regulation (TMR) ${ }^{5}$. However, these tests have so far not been specifically designed to detect endocrine disrupting effects. Therefore, there is an ongoing process of adaptation of the present EU legislative instruments, in order to take account of endocrine disrupting effects. The Nordic countries are looking for ways to elaborate the criteria for the identification of endocrine disrupters, and by reviewing present scientific knowledge on EDCs, evaluate how effective the present internationally standardized test methods are to capture endocrine disrupting properties.

The "OECD Guidance Document on Standardized Test Guidelines for Evaluating Chemicals for Endocrine Disruption" (2012) presents a comprehensive overview of internationally agreed and validated test methods for testing of chemicals and how to evaluate the results from these for endocrine disrupting properties. Within this document the Conceptual Framework (CF) lists available standardized Test Guidelines (TG) and test methods under development. These methods have been sorted in the CF based on the level or organisation, from in vitro assays at Level 2 to in vivo assays providing data on effects over more extensive parts of the life cycle of the organism at Level 5. Methods have also been sorted based on their relevance for either mammalian toxicology or nonmammalian toxicology.

The aim of the present study was to evaluate how well the methods used in available scientific publications manage to identify endocrine disruptors and to compare the outcome to the listed methods within the OECD Conceptual Framework (OECD 2012, Annex 1.4) and evaluate if

\footnotetext{
2 Regulation (EC) No 1907/2006 - the REACH regulation (REACH).

${ }^{3}$ Regulation (EU) No 528/2012 of the European Parliament and of the Council of 22 May 2012

concerning the making available on the market and use of biocidal products (BPR)

${ }^{4}$ Regulation (EC) No 1107/2009 - plant protection products (PPP)

${ }^{5}$ Regulation (EC) No 440/2008 of 30 May 2008 laying down test methods pursuant to Regulation (EC) No $1907 / 2006$ of the European Parliament and of the Council on the Registration, Evaluation, Authorisation and Restriction of Chemicals (REACH).
} 
the substance would likely be identified as an endocrine disrupter using the methods within the CF. Available scientific information, primarily from peer-reviewed scientific publications, on possible endocrine effects of three model substances was reviewed. The substances are

- Diuron

- Piperonyl butoxide (PBO)

- Resorcinol

Approximately 100 publications were reviewed and among these approximately 50 presented data from animal testing, or with bioassay testing, with one of the model substances. Only in one case did the authors specifically state that the testing had been conducted in accordance to one of the OECD Test Guidelines.

Firstly, this study presents a short literature review describing how well all methods used in the publications manage to identify endocrine disrupting effects of the three model substances.

Secondly, this study evaluated how well the methods within the OECD CF capture endocrine effects of the three model substances. Some of the reviewed studies had been conducted in a way similar 6 to standardized or proposed OECD Test Guidelines. Based on demonstrated effects in studies that resemble OECD Test Guidelines, the table below presents an overview of which of the TGs that are likely to identify endocrine effects.

Demonstrated effects in studies that closely resembles OECD Test Guidelines are indicated by a green box in the the table. The most resembling existing TG is named together with the endpoint giving positive results.

Demonstrated effects in studies with shared features of existing Test Guidelines but with deviating, or not yet standardized endpoints, are indicated by a yellow box in the table. In these cases the most resembling existing TG or test method under development is named together with suggestions or prerequisites necessary for a positive identification of endocrine effects of the model substance.

\footnotetext{
${ }^{6}$ This is is an estimation and not a complete vivisection of the fulfilment of OECD TGs for all studies. A complete comparison at a detailed level, including e.g. number of replicates and laboratory methodology, could not be performed within the context of this report. Also, many publications do not present all details necessary for such an evaluation.
} 
Will the OECD Test Guidelines capture endocrine effects of the three model substances? Conclusion based on demonstrated effects in studies that are similar to the guidelines.

\section{Color codes:}

The test will detect endocrine effects of the model substance

The test may detect endocrine effects of the model substance, if suggestions given in red are followed

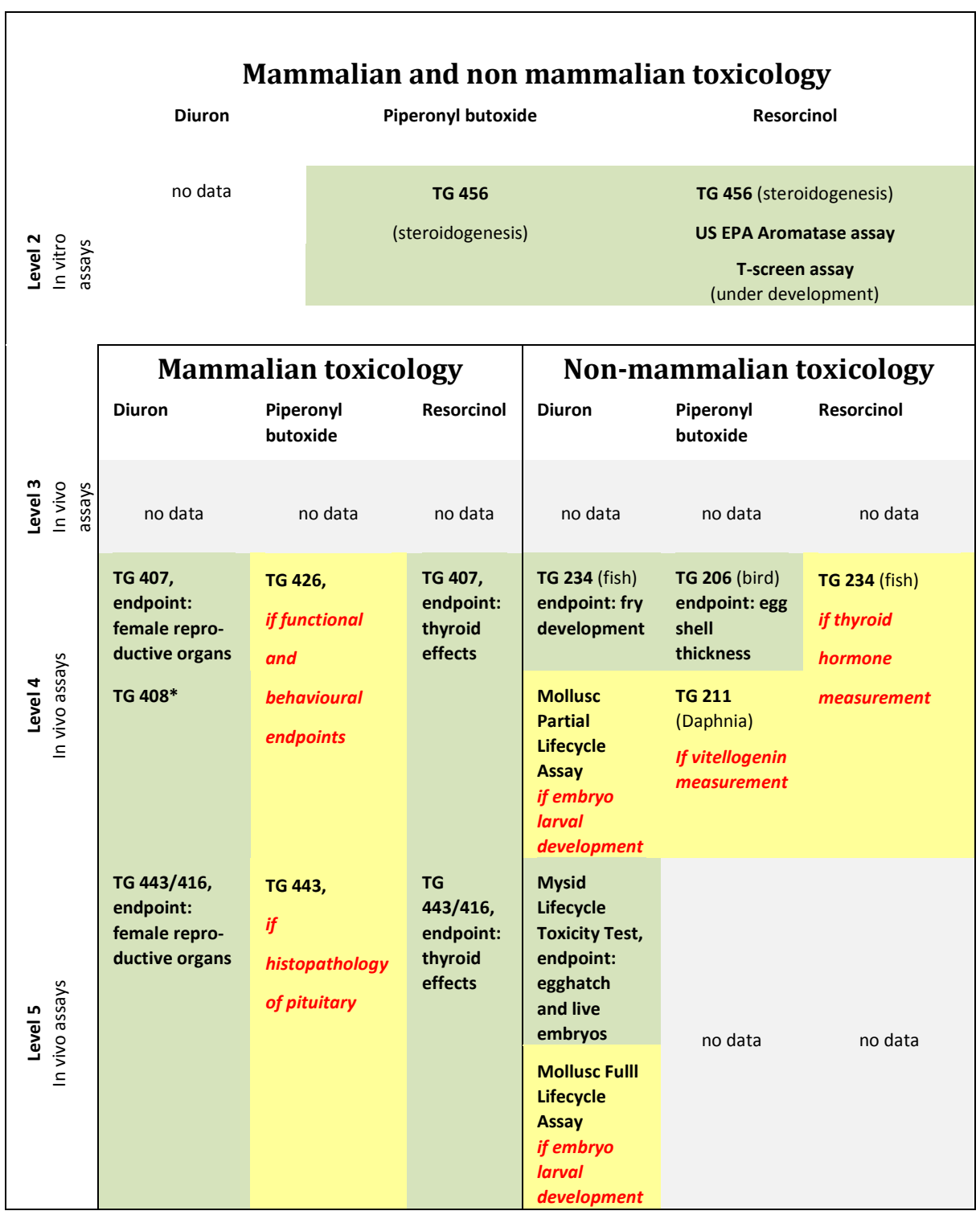

*No data available from long time exposure (90days) similar to TG 408 but the relevant endpoints of female reproductive organs will probably be as sensitive as TG 407. 
Based on the reviewed published studies on the three characterized chemicals, the following OECD methods are effective for capturing endocrine effects:

- Diuron has endocrine disruptive effects that can be discovered with the following mammalian and non-mammalian test methods within the OECD Conceptual Framework:

a) TG 416, TG 443, TG 407 and TG 408 for rodents

b) TG 234: Fish Sexual Development Test

- PBO has endocrine disruptive effects that to some extent can be discovered by the methods included in the OECD Conceptual Framework but PBO also has endocrine effects that can be missed out by these methods. Effective methods are:

a) TG 456 in vitro steroidogenesis

b) TG 206, Avian Reproduction Assay

- Resorcinol has endocrine disruptive effects that can be discovered with the following in vitro and mammalian test methods within the OECD Conceptual Framework:

a) TG 456 in vitro Steroidogenesis method

b) US EPA in vitro Aromatase Assay

c) Enhanced OECD TG 407 for rodents

d) TG 416 and TG 443 for rodents

Based on the reviewed published studies on the three characterized chemicals, the following recommendations are given:

- Non-mammalian Test Guidelines could be improved by the addition of thyroid related endpoints such as e.g. measurement of intrafollicular thyroid hormone in fish embryos.

- The model substance Piperonyl butoxide demonstrated that endocrine effects on the corticosteroid system will not be captured by the OECD CF. A mouse pituitary tumour cell line could possibly be a suitable method for in vitro screening of these effects at Level 2 of the OECD CF.

- Vitellogenin is a well known biomarker for estrogenic effects but the model substances piperonyl butoxide demonstrated that this biomarker also can be incorporated into TG 211 for evaluation of endocrine disruptive effects on ectysteroids. 
- Endocrine disruption by inhibition of P450 enzymes is both enzyme specific and species specific. More research is needed in this field in order to exclude the possibility of unpredicted endocrine effects cause by species specific interation of chemicals that have tested negative in standardized test guidelines.

Based on the reviewed published studies on the three characterized chemicals, the following general conclusions are drawn:

- The incorporation of thyroid related endpoints into existing standardized test methods with rodents provides a good "toolbox" to cover these endocrine effects for human safety.

- It is important to maintain a wide approach throughout the testing of possible endocrine effects of a chemical. Initial "estrogenic" effects in one experimental set up does not exclude the possibility of "androgenic" effects in another species or in another test method.

- Test Guidelines for Mollusc are currently being developed and the model substance diuron confirmed that these are sensitive species for detecting endocrine effects. 


\section{Introduction}

\subsection{Background}

Chemicals with endocrine disrupting effects (EDCs) need to be identified in order to comply with $\mathrm{REACH}^{7}$ and other relevant legislations. There is a need to further develop the criteria for how these potentially harmful chemicals can be identified. What criteria need to be fulfilled in order to identify a chemical as an endocrine disruptor? This is not yet fully defined and the European Commission has been mandated to specify this by the end of 2013 .

What methods for evaluation of EDCs are stipulated? To ensure that testing and assessment approaches for endocrine disruptors would not substantially differ among countries OECD established a special task force $^{8}$ that in August 2012 presented the latest version of a document on standardized test guidelines. The guidance document has been formally adopted as OECD guidance document no. 150 .

There are many different possible modes of action by which a chemical can cause an effect that is interpreted as an endocrine effect on the organism level. Since the modes of action are diverse, it is less likely that a universal test method can identify all sorts of endocrine disrupting chemicals.

There are substantial knowledge gaps concerning mode-of-action, low-dose effects, non-monotonic dose response curves, and the role of homeostasis for endocrine disrupting substances. Are the effects and endpoints studied in the present test methods required within REACH and other relevant legislations effective tools for identification of endocrine effects? Could some effects be missed out? These questions can be answered by:

1. compiling the scientific knowledge on a number of suspected endocrine disruptors,

2. evaluating the outcome from these studies,

3. and finally compare the methods used with the methods required within the legislation.

7 Regulation (EC) No 1907/2006 - the REACH regulation (REACH).

${ }^{8}$ Special Activity on Endocrine Disrupter Testing and Assessment (EDTA) 
In the current project information regarding three compounds was collected and analysed in a systematic manner.

\subsection{Objectives}

Available scientific publications reflect the current knowledge on endocrine disruptive properties of the three model substances (diuron, piperionyl butoxide (PBO) and resorcinol). The objectives of the study were to use this available information on these three suspected endocrine disruptors and compare to methods within the OECD Conceptual Framework (CF).

The first aim of the study was to evaluate how well the methods used in these publications manage to identify endocrine disruptors.

The second aim was to compare the methods used in the published material with the listed methods within the OECD CF (OECD 2012, Annex 1.4) and evaluate if the substances would likely be identified as endocrine disrupters using the methods within the CF. 


\section{Method}

Available scientific information, primarily from first hand peer-reviewed scientific publications, was reviewed. When available, test data with relevance for endocrine effects, was extracted from publications, compiled and organized into a database.

For each of the three model substances, the overall weight of evidence for endocrine disrupting properties were described in a review covering in vitro studies, mammalian in vivo studies and nonmammalian in vivo studies.

After reviewing all collected scientific publications extra attention was given to those studies that had been conducted in a way similar to standardized or proposed OECD Test Guidelines (TG) ${ }^{9}$. From this material it was possible to estimate which of the TGs that could identify the endocrine effects of the three model substances. These publications were also valuable for suggesting improvements of the TGs.

Publications presenting data from other types of tests not included in the Conceptual Framework (CF) gave valuable information on possible endocrine effects that would not be caught by the standardized methods.

\subsection{Substances}

The following three chemicals were evaluated as suggested by KemI and the NORAP-group:

1. Diuron (CAS no 330-54-1)

2. Piperonyl butoxide (CAS no 51-03-6)

3. Resorcinol (CAS no 108-46-3)

\footnotetext{
${ }^{9}$ In many cases detailed information on the experimental conditions, regarding e.g. number of test animals used was not presented in the publications and it was therefore difficult to determine the exact coherence with OECD Test Guidelines. An experiment conducted with the same test organism, the same exposure route, approximately the same duration and at least one identical endpoint, was considered comparable with a specific TG. Only one peer-reviewed paper by Welsch et al. (2008) clearly stated that the testing had been conducted according to OECD Test Guidelines.
} 


\subsection{Literature search}

A search tool performing simultaneous searching in a compilation of scientific databases was used to search for relevant data for all three substances. The search was conducted in October 2012. The search included, but was not restricted to, the following scientific databases:

- MathSciNet

- Medline

- Nature

- PubMed

- Science Citation Index (ISI)

- ScienceDirect

- SCIRUS

- SCOPUS

- SpringerLink

- Toxline

- Web of Science

- Wiley Online Library

Keywords used were e.g. "diuron + endocrin*", "diuron + endocrin* + oecd" and "diuron + in vivo".

The list of titles generated by the search was read and titles of possible relevance for the project were selected and downloaded according to the scope of the project. In the next step, the articles were read briefly and those with relevant information regarding endocrine effects of the specific chemical of interest were sorted out. A few specific articles of interest were also found by tracking the reference list of these articles.

Articles of interest were read and if containing experimental data this information was extracted and registered into an Access-database. If the experimental data was not first-hand experimental data, but cited data from another study, the original article was read when available.

\subsection{Database}

An Access-database was set up to compile data from the reviewed literature. With the aid of the database test results could in a simple manner be sorted based on different premises to e.g. compare only results from in vitro tests alone. 
In the database, reference information and abstracts for each publication was registered together with key information from the reported tests. The following key information was registered for each test:

- General method information: type of method, test organism and endpoint measured.

- Method organizational level: Studies were given an approximate level of organization according to the most similar standardized test found in the OECD Conceptual Framework (Level 1-5).

- Test concentrations/test doses: lowest tested, highest tested.

- Possible endocrine effects: Did the study indicate possible endocrine effects (+/-/inconclusive)? A subjective overall evaluation of the outcome of the study was done with a conservative approach. Besides obvious systematic effects on the endocrine system, reproductive toxicological effects, immunological effects and development in offspring were also considered as endocrine effects. All studies that could present a value for LOEC/LOED/EC50 or similar quantitative measures were considered positive (+). Also studies where the authors observed any relevant signs of endocrine effects or endocrine activity were considered positive $(+)$.

- Quantitative test results: When the publication contained endocrine relevant experimental data such as LO(A)EC, LO(A)EL, EC50, ED50, NO(A)EC or NO(A)EL, this data was registered in the data base. NO(A)EC or NO(A)EL were only registered from studies where the authors themselves used this terminology or in studies where data on effects at higher concentration could be presented.

\subsection{Evaluation}

The compiled literature review and a short summary based on this information will give an answer to how well the methods used in the publications manage to identify endocrine disrupting effects in the three model substances. Further, the extraction and organization of test data from a number of studies will give an overview of:

- From what type of methods are test data available? In vitro, mammalian in vivo or non-mammalian in vivo?

- What methods seem to be most sensitive (Lowes observed effect concentration)?

- What endpoints seem to be the most sensitive? 
Further the published studies were compared with methods within the regulatory framework (defined by the OECD CF as describe below). Only one peer-reviewed paper clearly stated that they had been conducted according to OECD Test Guidelines so the overall coherence with TGs had to be evaluated pragmatically as defined below. The relevancy of the test methods required within the legislation was evaluated based on the probable mode of action for the three model substances as evident from the literature review.

\subsection{Limitations and definitions}

One of the goals with the current study was to describe if there are effects (endpoints) identified that would not be caught by the present test methods required within the legislation $\left(\mathrm{REACH}^{10}, \mathrm{BPR}^{11}\right.$ and $\mathrm{PPP}{ }^{12}$ ) and/or by the Extended One- generation Reproductive Toxicity Study (EORGTS). Requirements for testing are included and connected to these legislations but the tests have not been specifically designed to detect endocrine effects. Therefore, there is currently an ongoing process of adaptation of the present EU legislative instruments, in order to take account of endocrine disrupting effects. As of today there are interim criteria that e.g. states that chemicals with toxic effects on endocrine glands are considered as endocrine disruptors according to PPP but within the next few years there will be more coherent scientific criteria and harmonized approach for testing of EDs.

According to the Community Strategy for Endocrine Disrupters ${ }^{13}$ adaptations of the legislative instruments are required. The Commission is now proposing to develop horizontal scientific criteria for identifying EDs that will apply to all relevant legislations including REACH.

«For the hazard identification stage, a key requirement for adaptation of existing legislation is the availability of test strategies/methods. There are currently no test strategies/methods available, which specifically detect all effects, which have been linked to the ED mechanism. However, the OECD has set up a Working Group on Endocrine Disrupters with the specific objective of developing a harmonised approach to the screening and testing of chemicals.»

\footnotetext{
${ }^{10}$ Regulation (EC) No 1907/2006 - the REACH regulation (REACH).

11 Regulation (EU) No 528/2012 of the European Parliament and of the Council of 22 May 2012

concerning the making available on the market and use of biocidal products (BPR)

12 Regulation (EC) No 1107/2009 - plant protection products (PPP).

${ }_{13} \mathrm{COM} / 99 / 0706$ Communication from the Commission to the Council and the European Parliament - Community strategy for endocrine disrupters - A range of substances suspected of interfering with the hormone systems of humans and wildlife.
} 
According to REACH, substances having endocrine disrupting properties may be added to the candidate list of Substances of Very High Concern (SVHC) and subsequently also be subjected to authorisation. These substances are identified on a case-by-case basis. The European Commission is mandated with reviewing the provisions of REACH regarding endocrine disruptors by 1 June 2013 .

As of today, the scientific criteria for the identification of biocides with ED properties have not yet been defined in the BPR regulation. The European Commission is required to specify this criteria no later than 13 December 2013.

Also the PPP regulation is in its current version uncompleted pending criteria for the definition of ED properties to be presented by the European Commission by 14 December 2013.

The OECD guidance documents were drafted in order to support regulatory decisions related to substances screened for endocrine disrupting properties and the CF presents the most comprehensive overview of internationally agreed and validated test methods. Methods required within the legislation, is within the context of this report defined as methods within the OECD CF. The latest version of the Conceptual Framework as presented in the OECD guidance document no. 150 is presented in Table 2.1 


\section{Table 2.1 The OECD Conceptual Framework as published in the Guidance Document (Aug 2012). Please note that TGs 456, TG 234 and TG 443 have since been adopted.}

\begin{tabular}{|c|c|}
\hline & Mammalian and non mammalian Toxicology \\
\hline $\begin{array}{l}\text { Level 1 } \\
\text { Existing Data and Non-Test } \\
\text { Information }\end{array}$ & $\begin{array}{l}\text { - Physical \& chemical properties, e.g., MW reactivity, volatility, biodegradability } \\
\text { - } \quad \text { All available (eco)toxicological data from standardized or non-standardized tests. } \\
\text { - Read across, chemical categories, QSARs and other in silico predictions, and ADME model predictions }\end{array}$ \\
\hline $\begin{array}{l}\text { Level 2 } \\
\text { In vitro assays providing data about } \\
\text { selected endocrine mechanism(s) / } \\
\text { pathways(s) } \\
\text { (Mammalian and non mammalian } \\
\text { methods) }\end{array}$ & $\begin{array}{ll}\text { - } & \text { Estrogen or androgen receptor binding affinity } \\
\text { - } & \text { Estrogen receptor transcriptional activation (TG 455) } \\
\text { - } & \text { Androgen or thyroid transcriptional activation (If/when TGs are available) } \\
\text { - } & \text { Steroidogenesis in vitro (draft TG } 456 \text { ) } \\
\text { - } & \text { Other assays as appropriferation assays (ER ant/agonist) } \\
\end{array}$ \\
\hline
\end{tabular}

\begin{tabular}{|l|}
\multicolumn{1}{|c|}{ Level 3 } \\
In vivo assays providing data about \\
selected endocrine mechanism(s) / \\
pathway(s)
\end{tabular}

\begin{tabular}{|l|}
\hline Level 4 \\
In vivo assays providing data on \\
adverse effects on endocrine \\
relevant endpoints
\end{tabular}

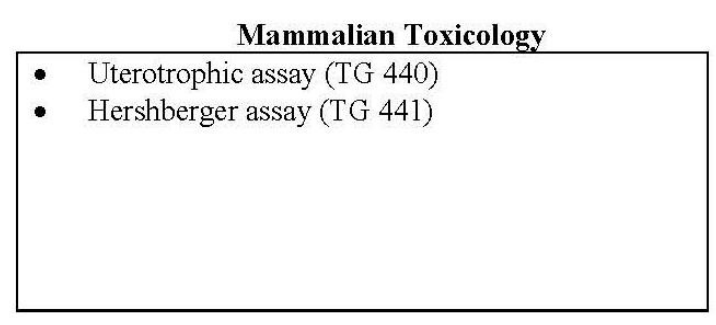

- Repeated dose 28-day study (TG 407)

- Repeated dose 90-day study (TG 408)

- 1-generation assay (TG 415)

- Male pubertal assay (see GD 150 [i.e.this GD] Chapter $\mathrm{C} 4.3)^{3}$

- Female pubertal assay (see GD 150 [i.e.this GD] Chapter $\mathrm{C} 4.4)^{3}$

- Intact adult male endocrine screening assay (see GD 150 [i.e.this GD] Chapter Annex 2.5)

- Prenatal developmental toxicity study (TG 414)

- Chronic toxicity and carcinogenicity studies (TG 451-3)

- Reproductive screening test (TG 421 if enhanced)
Xenopus embryo thyroid signalling assay (When/if TG is available)

- Amphibian metamorphosis assay (TG 231)

- Fish Reproductive Screening Assay (TG 229)

- Fish Screening Assay (TG 230)

- Androgenized female stickleback screen (GD 140)

- $\quad$ Fish sexual development test (Draft TG 234)

- Fish Reproduction Partial Lifecycle Test (when/If TG is Available)

- Larval Amphibian Growth \& Development Assay (when TG is available)

- Avian Reproduction Assay (TG 206)

- Mollusc Partial Lifecycle Assays (when TG is available $)^{4}$

- $\quad$ Chironomid Toxicity Test (TG 218-219) ${ }^{4}$ 


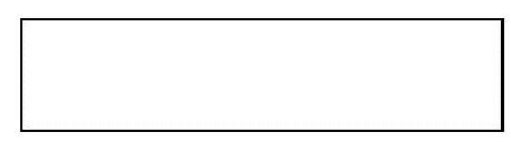

Level 5

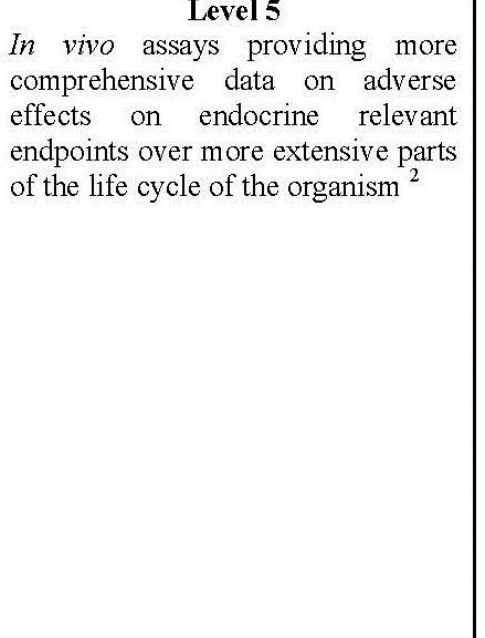

Combined 28 day/reproductive screening assay (TG 422 if enhanced)

- Developmental neurotoxicity (TG 426)

- Extended one-generation reproductive Toxicity Study (draft TG 443)

- 2-Generation assay (TG 416 most recent update)

Some assays may also provide some evidence of adverse effects.

2 Effects can be sensitive to more than one mechanism and may be due to non-ED mechanisms.

${ }^{3}$ Depending on the guideline/protocol used, the fact that a substance may interact with a hormone system in these assays does not necessarily mean that when the substance is used it will cause adverse effects in humans or ecological systems.

${ }^{4}$ At present, the available invertebrate assays solely involve apical endpoints which are able to respond to some endocrine disrupters and some non-EDs. Those in Level 4 are partial lifecycle tests, while those in Level 5 are full- or multiple lifecycle tests.

\section{Notes to the OECD Revised Conceptual Framework}

Note 1: Entering at all levels and exiting at all levels is possible and depends upon the nature of existing information and needs for testing and assessment.

Note 2: The assessment of each chemical should be based on a case by case basis, taking into account all available information, bearing in mind the function of the framework levels

Note 3: The framework should not be considered as all inclusive at the present time. At levels 2, 3, 4 and 5 it includes assays that are either available or for which validation is under way. With respect to the latter, these are provisionally included. 
There are different definitions of an endocrine disruptor and within the context of the OECD Guidance Document (OECD 2012) the WHO definition is used:

«An ED is an exogenous substance or mixture that alters function(s) of the endocrine system and consequently causes adverse health effects in an intact organism, or its progeny, or (sub) populations.»

(WHO, 2002)

When searching for available information regarding the three model substances a broad definition of endocrine effects and endpoints was considered including endpoints outside the EATS-modalities.

When comparing the available published studies with validated test methods in the OECD CF a more restricted approach was used. Firstly, a published study was considered comparable with a method within the OECD CF if the basic setup was comparable:

- Species used

- Experimental setup/route of exposure

- Study duration ${ }^{14}$

Table B1 in the OECD Guidance Document (2012) presents a listing of possible endpoints to cover the four EATS-modalities:

- Estrogen-mediated activity

- Androgen-mediated activity

- Thyroid-related activity

- Steroidogenesis disruption related activity

Secondly, a published study was considered to be comparable to a certain OECD TG if the studied endpoints were among the suggested for each TG in Table B1 in the OECD Guidance Document (2012).

A short summary of the available scientific information regarding possible ED effects of each model substance is presented. The term "weight of evidence" is used for this written summary of the reviewed literature. It should be stressed that the data material has not been evaluated according to specific guidelines in order to judge the scientific solidity of each test. The term is not used with reference to e.g. the guidance document from $\mathrm{ECHA}^{15}$ on how to report weight of evidence.

14 The time from starting the exposure to the time when the endpoint of interest was measured.

15 European Chemicals Agency. 2010. Practical guide 2: How to report weight of evidence. ECHA.Helsinki, Finland. 


\section{Results}

\subsection{Literature search}

Searching in databases, as described above, resulted in a list of article titles together with basic information on year of publication, authors and publication source. From the information given in publication title a great deal of these hits could be excluded as irrelevant. Among these hits where for example publications on method development for chemical analysis and publications on environmental data. Of the full articles downloaded approximately every second article was somehow relevant for the present review. With a few exceptions, the data entered into the database was from peer-reviewed publications. When the source is instead a report this is indicated in the tables with toxicity data below. An overview of the results from literature search is presented in Table 3.1 below.

Table 3.1 Overview of results from literature search (October 2012) for scientific articles with information on possible endocrine disrupting properties of three model compounds

\begin{tabular}{|l|l|l|l|}
\hline & $\begin{array}{l}\text { Diuron } \\
\text { (CAS no 330-54-1) }\end{array}$ & $\begin{array}{l}\text { Piperonyl butoxide } \\
\text { (CAS no 51-03-6) }\end{array}$ & $\begin{array}{l}\text { Resorcinol } \\
\text { (CAS no 108-46-3) }\end{array}$ \\
\hline $\begin{array}{l}\text { Approximate No. of article titles } \\
\text { reviewed }\end{array}$ & 316 & 105 & 208 \\
\hline No. of full articles downloaded & 59 & 83 & 76 \\
\hline No. of relevant articles reviewed & 32 & 46 & 32 \\
\hline $\begin{array}{l}\text { No. of articles with at least one data } \\
\text { value, from endocrine testing, } \\
\text { registered into the database. }\end{array}$ & 20 & 11 & 18 \\
\hline
\end{tabular}

\subsection{Diuron}

Diuron is a priority substance (2008/105EU Directive) and is a nonselective herbicide derived from urea, is highly persistent in the environment and is a known probable carcinogen (Teijon et al. 2010). 
Diuron has the following harmonized classification:

- Carc. 2 - Suspected of causing cancer

- Acute Tox. 4 - Harmful if swallowed

- STOT RE 2 - May cause damage to organs through prolonged or repeated exposure

- Aquatic Acute 1 - Very toxic to aquatic life

- Aquatic Chronic 1 - Very toxic to aquatic life with long lasting effects

(Source: European Chemicals Agency, http://echa.europa.eu/)

\section{Data review}

\section{In vitro studies}

In vitro studies have shown anti-estrogenic properties at 0.98-31.3 $\mu \mathrm{M}$ and anti-androgenic properties at 15.6-31.3 $\mu \mathrm{M}$ with yeast estrogen screen (YES) and yeast androgen screen (YAS) respectively (Orton et al. 2009). The anti-estrogenic potency of diuron was stronger than the similar phenyl urea herbicides isoproturon and linuron and the antiandrogenic potency of diuron was stronger than isoproturon but weaker than linuron. Anti-androgenic potency with weaker relative binding affinity to the AR in comparison with linuron was also shown in vitro with a calf uterus cytosol assay (Bauer et al. 1998).

No dose-dependent response curve was shown for estrogenic activity tested with another in vitro yeast assay (Noguerol et al. 2006).

At a concentration of $62.5 \mu \mathrm{M}$ diuron depressed testosterone production and ovulation in a frog (Xenopus laevis) oocyte in vitro assay (Orton et al. 2009). In an in vitro assay with fish (Cyprinus carpio) testicular cells, diuron did not have any effect on various enzymes involved in steroid synthesis and metabolism at a concentration of $100 \mu \mathrm{M}$ (Thibaut and Porte 2004).

An in vitro study with rainbow trout aromatase did not indicate that diuron has any direct inhibitory effect on aromatase enzymatic activity through direct interaction with the enzymatic complex (Hinfray et al. 2006). Diuron did not affect CYP19 aromatase in a human placenta in vitro assay (Vinggaard et al. 2000).

Diuron was not an active ligand for peroxisome proliferator-activated receptors (PPARs) in an in vitro assay with CV-1 monkey kidney cells (Takeuchi et al. 2006). This is relevant for concern of endocrine disruption since the binding of some ligands, such as mono-(2-ethylhexyl) 
phthalate, to PPAR leads to a decrease of aromatase mRNA levels which may in turn affect steroidogenesis (Takeuchi et al. 2006).

AhR activity of diuron has been shown in vitro as CYP1A1 was up regulated in a human cell line assay at a concentration of 50-100 $\mu \mathrm{M}$ (Marco et al. 2012).

\section{Mammalian toxicology}

Fernandes et al. (2007) reported a decrease in number of foetuses in female rats inseminated by males treated with $125 \mathrm{mg} / \mathrm{kg} / \mathrm{bw} / \mathrm{d}$ of diuron during 30 days but in the same study there were no discovered effects on a number of other endpoints. Only males were exposed and among the other endpoints studied were e.g. male histopathology, male sexual behaviour and plasma testosterone concentrations. In the current review this study was considered inconclusive as the effect on reproductive success suggested the need for additional studies but could not alone be regarded as an endocrine effect. Female reproductive toxicology, indicated as reduced weight of ovaries and reduced Corpora lutea, has been reported in offspring to rats fed with $1250 \mathrm{ppm}$ of diuron (Grassi et al. 2011). Effects on the hormone production of the ovaries are a plausible secondary effect but no shift in hormone production was observed in offspring from diuron-fed parents. The conclusion from the study by Grassi et al. (2011) is that diuron did not induce systemic hormonal perturbation or mammary alterations under the conditions of the experiment.

AhR activity and CYP1A induction of diuron has been demonstrated in vivo after intraperitoneal injection of $300 \mathrm{mg} / \mathrm{kg} / \mathrm{bw}$ in mouse (Takeuchi 2008).

\section{Non-mammalian toxicology}

A very strong evidence for the endocrine disruptive effects of diuron was presented by Cardone et al. (2008). When lizards (Podarcis sicula) were simultaneously exposed from polluted soil in terraria and also from ingestion of diuron-treated food and/or water a number of effects on the reproductive organs were shown. Severe testicular effects were reported such as for example: a $55 \%$ reduction in gonado-somatic index in comparison to control group and a $92 \%$ decrease in crude numbers of spermatozoa. Some of the reported effects might be related to the degradation product 3,4-dichloroaniline. Diuron has AR activity but 3,4dichloroanlinine is in fact slightly more active (Bauer et al. 1998). 
Diuron did not affect egg hatch or fish growth for Fathead minnow (Pimephales promelas) at a concentration of $78 \mu \mathrm{g} / \mathrm{l}$, however the same concentration caused a significant increased incidence of abnormal or dead fry (Call et al. 1987). Diuron may induce behavioural alterations in fish at a concentration of $5 \mu \mathrm{g} / \mathrm{l}$ (Saglio et al. 1998). Goldfish (Carassius auratus) exposed for $24 \mathrm{~h}$ showed significant burst swimming reactions.

Diuron has reproductive effects on oyster at a concentration of 0.5 $\mu \mathrm{g} / \mathrm{l}$ (Akcha et al. 2012). These were genotoxic effects on spermatozoa and not necessary regarded as mediated by endocrine mechanisms. Other exposure studies with oyster (Crassotrea gigas) have indicated effects of diuron on the reproductive cycle at a concentration of $1 \mu \mathrm{g} / \mathrm{l}$ (Buisson et al. 2008). Further, diuron has an immunological effect on oyster and exposure of $0.8 \mu \mathrm{g} / \mathrm{l}$ for 2 hours changes the activity of enzymes implicated in immune defence mechanisms (Luna-Acosta et al. 2012).

Reproductive effects, that not necessary are mediated through endocrine mechanism, has also been shown for springtails (Collembola) at a soil concentration of $20 \mathrm{mg} / \mathrm{kg}$ (Campriche et al. 2006).

The LOEC for reproductive toxicity to the estuarine invertebrate mysid shrimp (Americamysis bahia) was $0.56 \mu \mathrm{g} / \mathrm{l}$ in a study that has been quality approved by EPA Environmental fate and effects division (EFED) (Turner 2003).

High concentration of diuron $(1000 \mu \mathrm{g} / \mathrm{l})$ did not inhibit the fertilization of two species of corals but metamorphosis was affected for Acropora millipora at $300 \mu \mathrm{g} / \mathrm{l}$ (Negri et al. 2005). The mechanism behind this effect is unknown.

\section{Toxicity data}

An overview of toxicity data on possible endocrine effects of diuron is presented in Table 3.2 below. 
Table 3.2 Overview of toxicity data on possible endocrine effects of diuron

\begin{tabular}{|c|c|c|c|c|c|c|c|c|c|}
\hline & Organism & Method & Endpoint & $\begin{array}{c}\text { Possible } \\
\text { endocrine } \\
\text { effects }^{a}\end{array}$ & LOEC/LOEL/EC50 & NOEL $^{b}$ & $\begin{array}{l}\text { Lowest tested } \\
\text { concentration/dose }\end{array}$ & $\begin{array}{l}\text { Highest tested } \\
\text { concentration/dose }\end{array}$ & Reference \\
\hline \multirow{12}{*}{ 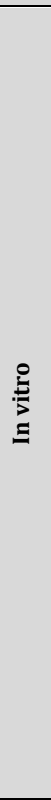 } & & YES & $\begin{array}{l}\text { ER binding / } \\
\text { enzyme activity }\end{array}$ & inc. & $\begin{array}{c}\text { EC50 200mg/l } \\
(860 \mu \mathrm{M})\end{array}$ & & & & $\begin{array}{l}\text { Noguerol, T-N., Boronat, S., Casado, M., Raldúa, D., } \\
\text { Barceló, D., Piña, B. (2006) }\end{array}$ \\
\hline & & YES & $\begin{array}{l}\text { ER binding / } \\
\text { enzyme activity }\end{array}$ & + & $0,98 \mu \mathrm{M}$ & & $0,01 \mu \mathrm{M}$ & $1000 \mu \mathrm{M}$ & Orton, F., Lutz, l., Kloas, W., Routledge, E. (2009) \\
\hline & & YAS & $\begin{array}{l}\text { AR binding / } \\
\text { enzyme activity }\end{array}$ & + & $15,6 \mu \mathrm{M}$ & & $0,01 \mu \mathrm{M}$ & $1000 \mu \mathrm{M}$ & Orton, F., Lutz, I., Kloas, W., Routledge, E. (2009) \\
\hline & & human hepG2 cell assay & $\begin{array}{l}\text { enzyme activity } \\
\text { (CYP1A1) }\end{array}$ & + & $50 \mu \mathrm{M}$ & & $50 \mu \mathrm{M}$ & $100 \mu \mathrm{M}$ & $\begin{array}{l}\text { Marco, F., Grazia Sacco, M., Roumengous, S., Collotta, A., } \\
\text { Laura, G. (2012) }\end{array}$ \\
\hline & $\begin{array}{l}\text { Xenopus } \\
\text { laevis }\end{array}$ & frog oocyte cell assay & $\begin{array}{l}\text { Steroidogenesis } \\
\text { (progesterone, } \\
\text { testosterone) } \\
\end{array}$ & + & $62,5 \mu \mathrm{M}$ & & $0,00625 \mu \mathrm{M}$ & $62,5 \mu \mathrm{M}$ & Orton, F., Lutz, I., Kloas, W., Routledge, E. (2009) \\
\hline & $\begin{array}{l}\text { Cyprinus } \\
\text { carpio }\end{array}$ & carp testicular cell assay & steroidogenesis & - & & $100 \mu \mathrm{M}$ & & $100 \mu \mathrm{M}$ & Thibaut, R., Porte, C. (2004) \\
\hline & & Human placenta cell assay & aromatase activity & - & & $50 \mu \mathrm{M}$ & & $50 \mu \mathrm{M}$ & $\begin{array}{l}\text { Vinggaard, A.M., Hnida, C., Breinholt, V., Larsen, J.C. } \\
(2000)\end{array}$ \\
\hline & & $\begin{array}{c}\text { human Lymph Node Carci- } \\
\text { noma of Prostate (LNCaP) } \\
\text { cell assay } \\
\end{array}$ & $\begin{array}{l}\text { 5alpha-reductase } \\
\text { activity }\end{array}$ & - & & $24 \mu \mathrm{M}$ & & $24 \mu \mathrm{M}$ & Lo, S., King, I., Alléra, A., Klingmüller, D., (2007) \\
\hline & & $\begin{array}{l}\text { human prostate tissue } \\
\text { homogenate cell assay }\end{array}$ & $\begin{array}{c}\text { 5alpha-reductase } \\
\text { activity }\end{array}$ & - & & $24 \mu \mathrm{M}$ & & $24 \mu \mathrm{M}$ & Lo, S., King, I., Alléra, A., Klingmüller, D., (2007) \\
\hline & $\begin{array}{l}\text { Oncorhyn- } \\
\text { chus mykiss }\end{array}$ & $\begin{array}{l}\text { rainbow trout brain aroma- } \\
\text { tase assay }\end{array}$ & enzyme activity & - & & $10 \mu \mathrm{M}$ & & $10 \mu \mathrm{M}$ & Hinfray, N., Porcher, J-M., Brion, F. (2006) \\
\hline & $\begin{array}{l}\text { Oncorhyn- } \\
\text { chus mykiss }\end{array}$ & $\begin{array}{l}\text { rainbow trout ovary aroma- } \\
\text { tase assay }\end{array}$ & enzyme activity & - & & $10 \mu \mathrm{M}$ & & $10 \mu \mathrm{M}$ & Hinfray, N., Porcher, J-M., Brion, F. (2006) \\
\hline & & $\begin{array}{l}\text { PPARs assay, CV-1 monkey } \\
\text { kidney cells }\end{array}$ & enzyme activity & - & & $10 \mu \mathrm{M}$ & & $10 \mu \mathrm{M}$ & $\begin{array}{c}\text { Takeuchi, S., Matsuda, T., Kobayashi, S., Takahashi, T., } \\
\text { Kojima, H. (2006) }\end{array}$ \\
\hline
\end{tabular}

a The qualitative result of the study was evaluated as described in section 2.3 above.

b NOEL was only registered when authors used this terminology or in cases where data on effects at higher concentration was presented. 
Table 3.2 continued Overview of toxicity data on possible endocrine effects of diuron

\begin{tabular}{|c|c|c|c|c|c|c|c|c|c|}
\hline & Organism & Method & Endpoint & $\begin{array}{c}\text { Possible } \\
\text { endocrine } \\
\text { effects }\end{array}$ & LOEC/LOEL/EC5O & NOEL $^{b}$ & $\begin{array}{l}\text { Lowest tested } \\
\text { concentra- } \\
\text { tion/dose } \\
\end{array}$ & $\begin{array}{c}\text { Highest tested } \\
\text { concentration/dose }\end{array}$ & Reference \\
\hline \multirow{11}{*}{ 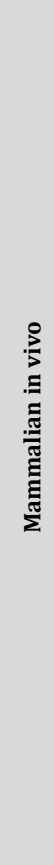 } & rat & $\begin{array}{l}\text { repeated oral } \\
\text { dose } 30 \text { days }\end{array}$ & reproductive success & Inc. $^{c}$ & $125 \mathrm{mg} / \mathrm{kg} / \mathrm{bw} / \mathrm{d}$ & & $\begin{array}{c}125 \\
\mathrm{mg} / \mathrm{kg} / \mathrm{bw} / \mathrm{d}\end{array}$ & $250 \mathrm{mg} / \mathrm{kg} / \mathrm{bw} / \mathrm{d}$ & $\begin{array}{c}\text { Fernandes, G., Arena, A., Fernandez, C., Mercadante, A., } \\
\text { Barbisan, L., Kempinas, W. (2007) }\end{array}$ \\
\hline & rat & $\begin{array}{c}\text { Perinatal and } \\
\text { juvenile exposure }\end{array}$ & $\begin{array}{l}\text { growth and develop- } \\
\text { ment in offspring }\end{array}$ & Inc. $^{d}$ & $750 \mathrm{ppm}$ & & $500 \mathrm{ppm}$ & $750 \mathrm{ppm}$ & $\begin{array}{l}\text { Fernandes, G., Favareto, A., Fernandez, C., Bellentani, F., } \\
\text { Arena, A., Grassi, T., Kempinas, W., Barbisan, F. (2012) }\end{array}$ \\
\hline & $\begin{array}{l}\text { rat Sprague- } \\
\text { Dawley }\end{array}$ & $\begin{array}{l}\text { Perinatal and } \\
\text { juvenile exposure }\end{array}$ & corpora lutea weight & + & $1250 \mathrm{ppm}$ & & $500 \mathrm{ppm}$ & $1250 \mathrm{ppm}$ & $\begin{array}{c}\text { Grassi, T., Trevisan Guerra, M., Perobelli, J., Choqueta de } \\
\text { Toledo, F., Salioni da Silva, D., De Grava Kempinas, W. and } \\
\text { Barbisan, L. (2011) }\end{array}$ \\
\hline & $\begin{array}{l}\text { rat Sprague- } \\
\text { Dawley }\end{array}$ & $\begin{array}{l}\text { Perinatal and } \\
\text { juvenile exposure }\end{array}$ & ovaries weight & + & $1250 \mathrm{ppm}$ & & $500 \mathrm{ppm}$ & $1250 \mathrm{ppm}$ & $\begin{array}{c}\text { Grassi, T., Trevisan Guerra, M., Perobelli, J., Choqueta de } \\
\text { Toledo, F., Salioni da Silva, D., De Grava Kempinas, W. and } \\
\text { Barbisan, L. (2011) } \\
\end{array}$ \\
\hline & rat & $\begin{array}{c}\text { Perinatal and } \\
\text { juvenile exposure }\end{array}$ & $\begin{array}{l}\text { reproductive toxicologi- } \\
\text { cal effects in offspring }\end{array}$ & - & & & $500 \mathrm{ppm}$ & $750 \mathrm{ppm}$ & $\begin{array}{l}\text { Fernandes, G., Favareto, A., Fernandez, C., Bellentani, F., } \\
\text { Arena, A., Grassi, T., Kempinas, W., Barbisan, F. (2012) }\end{array}$ \\
\hline & rat & $\begin{array}{l}\text { repeated oral } \\
\text { dose } 30 \text { days }\end{array}$ & male sexual behaviour & - & & & $\begin{array}{c}125 \\
\mathrm{mg} / \mathrm{kg} / \mathrm{bw} / \mathrm{d}\end{array}$ & $250 \mathrm{mg} / \mathrm{kg} / \mathrm{bw} / \mathrm{d}$ & $\begin{array}{l}\text { Fernandes, G., Arena, A., Fernandez, C., Mercadante, A., } \\
\text { Barbisan, L., Kempinas, W. (2007) }\end{array}$ \\
\hline & rat & $\begin{array}{l}\text { repeated oral } \\
\text { dose } 30 \text { days }\end{array}$ & $\begin{array}{l}\text { sperm count and } \\
\text { morphology }\end{array}$ & - & & & $\begin{array}{c}125 \\
\mathrm{mg} / \mathrm{kg} / \mathrm{bw} / \mathrm{d}\end{array}$ & $250 \mathrm{mg} / \mathrm{kg} / \mathrm{bw} / \mathrm{d}$ & $\begin{array}{c}\text { Fernandes, G., Arena, A., Fernandez, C., Mercadante, A., } \\
\text { Barbisan, L., Kempinas, W. (2007) }\end{array}$ \\
\hline & rat & $\begin{array}{l}\text { repeated oral } \\
\text { dose } 30 \text { days }\end{array}$ & testis, histological & - & & & $\begin{array}{c}125 \\
\mathrm{mg} / \mathrm{kg} / \mathrm{bw} / \mathrm{d}\end{array}$ & $250 \mathrm{mg} / \mathrm{kg} / \mathrm{bw} / \mathrm{d}$ & $\begin{array}{c}\text { Fernandes, G., Arena, A., Fernandez, C., Mercadante, A., } \\
\text { Barbisan, L., Kempinas, W. (2007) }\end{array}$ \\
\hline & $\begin{array}{l}\text { rat Sprague- } \\
\text { Dawley }\end{array}$ & $\begin{array}{l}\text { Perinatal and } \\
\text { juvenile exposure }\end{array}$ & mammary morphology & - & & & $500 \mathrm{ppm}$ & $1250 \mathrm{ppm}$ & $\begin{array}{l}\text { Grassi, T., Trevisan Guerra, M., Perobelli, J., Choqueta de } \\
\text { Toledo, F., Salioni da Silva, D., De Grava Kempinas, W. } \\
\text { and Barbisan, L. (2011) } \\
\end{array}$ \\
\hline & $\begin{array}{l}\text { rat Sprague- } \\
\text { Dawley }\end{array}$ & $\begin{array}{l}\text { Perinatal and } \\
\text { juvenile exposure }\end{array}$ & estrus cycle & - & & & $500 \mathrm{ppm}$ & $1250 \mathrm{ppm}$ & $\begin{array}{l}\text { Grassi, T., Trevisan Guerra, M., Perobelli, J., Choqueta de } \\
\text { Toledo, F., Salioni da Silva, D., De Grava Kempinas, W. } \\
\text { and Barbisan, L. (2011) } \\
\end{array}$ \\
\hline & $\begin{array}{l}\text { rat Sprague- } \\
\text { Dawley }\end{array}$ & $\begin{array}{c}\text { Perinatal and } \\
\text { juvenile exposure }\end{array}$ & $\begin{array}{l}\text { vaginal opening accel- } \\
\text { erated }\end{array}$ & - & & & $500 \mathrm{ppm}$ & $1250 \mathrm{ppm}$ & $\begin{array}{l}\text { Grassi, T., Trevisan Guerra, M., Perobelli, J., Choqueta de } \\
\text { Toledo, F., Salioni da Silva, D., De Grava Kempinas, W. } \\
\text { and Barbisan, L. (2011) }\end{array}$ \\
\hline
\end{tabular}

a The qualitative result of the study was evaluated as described in section 2.3 above.

b NOEL was only registered when authors used this terminology or in cases where data on effects at higher concentration was presented.

${ }^{c}$ Decreased number of foetuses, not indicative of ED

d Male offspring toxicity (reduce body weight), not indicative of ED 


\begin{tabular}{|c|c|c|c|c|c|c|c|c|c|}
\hline & Organism & Method & Endpoint & $\begin{array}{l}\text { Possible } \\
\text { endo- } \\
\text { crine } \\
\text { effects }\end{array}$ & LOEC/LOEL/EC50 & NOEL ${ }^{b}$ & $\begin{array}{l}\text { Lowest tested } \\
\text { concentration/dose }\end{array}$ & $\begin{array}{l}\text { Highest tested } \\
\text { concentration/dose }\end{array}$ & Reference \\
\hline \multirow{14}{*}{ 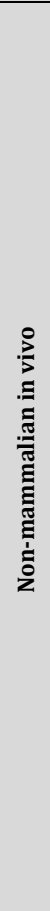 } & & $\begin{array}{l}\text { oyster embryo-larval } \\
\text { bioassay }\end{array}$ & $\begin{array}{l}\text { larval abnormali- } \\
\text { ties }\end{array}$ & + & $0,05 \mu \mathrm{g} / \mathrm{l}$ & & $0,05 \mu \mathrm{g} / \mathrm{l}$ & $0,5 \mu \mathrm{g} / \mathrm{l}$ & Akcha, F., Spagnol, C., Rouxel, J. (2012) \\
\hline & $\begin{array}{c}\text { Americamysis } \\
\text { bahia }\end{array}$ & $\begin{array}{l}\text { evertebrate } 28 \text { day life } \\
\text { cycle test }\end{array}$ & $\begin{array}{c}\text { egghatch and } \\
\text { number of live } \\
\text { embryos }\end{array}$ & + & $0,56 \mu \mathrm{g} / \mathrm{l}$ & $0,27 \mu \mathrm{g} / \mathrm{l}$ & & & Turner, L. (2003) \\
\hline & $\begin{array}{l}\text { Crassotrea } \\
\text { gigas }\end{array}$ & mollusc immunological & enzyme activity & + & $0,8 \mu \mathrm{g} / \mathrm{l}$ & & $0,8 \mu \mathrm{g} / \mathrm{l}$ & $0,8 \mu \mathrm{g} / \mathrm{l}$ & $\begin{array}{l}\text { Luna-Acosta, A., Renault, T., Thomas-Guyon, H., Faury, N., } \\
\text { Saulnier, D., Budzinski, H. (2012) }\end{array}$ \\
\hline & $\begin{array}{c}\text { Crassotrea } \\
\text { gigas }\end{array}$ & $\begin{array}{l}\text { mollusc reproductive } \\
\text { cycle }\end{array}$ & spawning & + & $1 \mu \mathrm{g} / \mathrm{l}$ & & $0,1 \mu \mathrm{g} / \mathrm{l}$ & $10 \mu \mathrm{g} / \mathrm{l}$ & $\begin{array}{l}\text { Buisson, S., Bouchart, V., Guerlet, E., Malas, J., Costil, K. } \\
\qquad(2008)\end{array}$ \\
\hline & $\begin{array}{c}\text { Carassius } \\
\text { auratus }\end{array}$ & $\begin{array}{l}\text { fish behaviour } 24 \mathrm{~h} \\
\text { exposure }\end{array}$ & $\begin{array}{l}\text { behaviour, burst } \\
\text { swimming reaction }\end{array}$ & + & $5 \mu \mathrm{g} / \mathrm{l}$ & $0,5 \mu \mathrm{g} / \mathrm{l}$ & $0,5 \mu \mathrm{g} / \mathrm{l}$ & $50 \mu \mathrm{g} / \mathrm{l}$ & Saglio, P., Trijasse, S. (1998) \\
\hline & $\begin{array}{l}\text { Pimephales } \\
\text { promelas }\end{array}$ & $\begin{array}{l}\text { fish early life stage } \\
\text { toxicity }\end{array}$ & fry development & + & $78 \mu \mathrm{g} / \mathrm{l}$ & $33,4 \mu \mathrm{g} / \mathrm{l}$ & $2,6 \mu \mathrm{g} / \mathrm{l}$ & $78 \mu \mathrm{g} / \mathrm{l}$ & $\begin{array}{l}\text { Call, D. J., Brooke, L. T., Kent, R. J., Knuth, M. L., Poirier, S. } \\
\text { H., Huot, J. M., Lima, A.R. (1987) }\end{array}$ \\
\hline & $\begin{array}{l}\text { Acropora } \\
\text { millepora }\end{array}$ & coral life history stages & metamorphosis & + & $300 \mu \mathrm{g} / \mathrm{l}$ & & $1 \mu \mathrm{g} / \mathrm{l}$ & $1000 \mu \mathrm{g} / \mathrm{l}$ & $\begin{array}{l}\text { Negri, A., Vollhardt, C., Humphrey, C., Heyward, A., } \\
\text { Jones,R., Eaglesham, G., Fabricius, K. (2005) }\end{array}$ \\
\hline & $\begin{array}{l}\text { Folsomia } \\
\text { candida }\end{array}$ & Collembola 28 day & $\begin{array}{l}\text { survival and } \\
\text { reproduction }\end{array}$ & + & 20 mg/kg soil & & $1,6 \mathrm{mg} / \mathrm{kg}$ soil & $1000 \mathrm{mg} / \mathrm{kg}$ soil & $\begin{array}{c}\text { Campiche, S., Becker-van Slooten, K., Ridreau, C., Tar- } \\
\text { radellas, J. (2006) }\end{array}$ \\
\hline & $\begin{array}{l}\text { Podarcis } \\
\text { sicula }\end{array}$ & $\begin{array}{l}\text { lizard } 3 \text { week continuous } \\
\text { exposure soil/water/food }\end{array}$ & testis, histological & + & & & & & Cardone, A., Comitato, R., Angelini, F. (2008) \\
\hline & $\begin{array}{c}\text { Podarcis } \\
\text { sicula }\end{array}$ & $\begin{array}{l}\text { lizard } 3 \text { week continuous } \\
\text { exposure soil/water/food }\end{array}$ & $\begin{array}{c}\text { gonado-somatic } \\
\text { index }\end{array}$ & + & & & & & Cardone, A., Comitato, R., Angelini, F. (2008) \\
\hline & $\begin{array}{l}\text { Podarcis } \\
\text { sicula }\end{array}$ & $\begin{array}{l}\text { lizard } 3 \text { week continuous } \\
\text { exposure soil/water/food }\end{array}$ & $\begin{array}{l}\text { serum testos- } \\
\text { terone levels }\end{array}$ & + & & & & & Cardone, A., Comitato, R., Angelini, F. (2008) \\
\hline & $\begin{array}{l}\text { Podarcis } \\
\text { sicula }\end{array}$ & $\begin{array}{l}\text { lizard } 3 \text { week continuous } \\
\text { exposure soil/water/food }\end{array}$ & $\begin{array}{l}\text { reproductive } \\
\text { toxicological } \\
\text { effects, parents }\end{array}$ & + & & & & & Cardone, A., Comitato, R., Angelini, F. (2008) \\
\hline & $\begin{array}{l}\text { Acropora } \\
\text { millepora }\end{array}$ & coral life history stages & $\begin{array}{l}\text { reproductive } \\
\text { success }\end{array}$ & - & & $1000 \mu \mathrm{g} / \mathrm{l}$ & $1 \mu \mathrm{g} / \mathrm{l}$ & $1000 \mu \mathrm{g} / \mathrm{l}$ & $\begin{array}{l}\text { Negri, A., Vollhardt, C., Humphrey, C., Heyward, A., } \\
\text { Jones,R., Eaglesham, G., Fabricius, K. (2005) }\end{array}$ \\
\hline & $\begin{array}{l}\text { Pimephales } \\
\text { promelas }\end{array}$ & fish reproductive & $\begin{array}{c}\text { reproductive } \\
\text { success }\end{array}$ & - & & $78 \mu \mathrm{g} / \mathrm{l}$ & $2,6 \mu \mathrm{g} / \mathrm{l}$ & $78 \mu \mathrm{g} / \mathrm{l}$ & $\begin{array}{l}\text { Call, D. J., Brooke, L. T., Kent, R. J., Knuth, M. L., Poirier, S. } \\
\text { H., Huot, J. M., Lima, A.R. (1987) }\end{array}$ \\
\hline
\end{tabular}

a The qualitative result of the study was evaluated as described in section 2.3 above.

b NOEL was only registered when authors used this terminology or in cases where data on effects at higher concentration was presented. 


\subsection{Piperonyl butoxide}

Piperonyl butoxide (PBO) is known to inhibit microsomal enzymes in insects. This property is exploited in several formulated products of pesticides where $\mathrm{PBO}$ is combined with other pesticides. A resulting synergistic effect is given when PBO prevents the enzymatic breakdown of the other active insecticides. PBO also inhibits microsomal enzymes in mammalian cells. This property is exploited when PBO is used as a classical compound in pharmacological experiments to compare the therapeutic or toxicological effect of several drugs before or after metabolism in mammalian systems.

PBO has not been classified due to insufficient data but has the following reported hazards:

- Aquatic Chronic 2 - Toxic to aquatic life with long lasting effects.

(Source: European Chemicals Agency, http://echa.europa.eu/)

\section{Data review}

\section{In vitro studies}

In vitro studies with trout hepatocytes have shown that PBO strongly inhibits certain P450 monooxygenase activities at a concentration of 100 $\mu \mathrm{M}$ (Miranda 1998). PBO strongly inhibited the progesterone 6 $\beta$ hydroxylase activity and hence may affect steroidogenesis in fish. This enzymatic activity is catalysed by CYP3A27 in trout.

PBO was tested for (anti-)estrogenic and (anti-)androgenic effect in the OECD-standardized H295R steroidogenesis in vitro assay (Hecker et al. 2011). PBO tested negative for $\mathrm{E} 2$ production with $100 \mu \mathrm{M}$ as the highest tested concentration and the LOEC for testosterone production was $10 \mathrm{mg} / \mathrm{l}(30 \mu \mathrm{M})$.

Immune cells, preferably B-cells, responded with a higher incidence of apoptosis when treated with $55 \mu \mathrm{M}$ of PBO in a cell assay with mouse spleen cells (Battaglia et al. 2010). 


\section{Mammalian toxicology}

PBO may, via the inhibitory effect on P450, have impacts on the release of corticotropin from the pituitary in rats (Okajima and Hertting 1986) and in mouse (Luini and Axelrod 1985).

Prolonged exposure of higher doses $(32 \mathrm{mg} / \mathrm{kg} / \mathrm{bw} / \mathrm{d})$ of PBO causes increased adrenal weights in dogs, besides increased weight of liver and kidney (EPA 2000).

PBO showed adverse effects on the motor activity of the exploratory behaviour in male mice exposed to $827-953 \mathrm{mg} / \mathrm{kg} / \mathrm{bw} / \mathrm{d}$ via food (Tanaka 1993).

Behavioural endpoints have also been studied in exposure studies with rodents over two generations. For mice, Tanaka (1992) found that prolonged dietary exposure of circa $450 \mathrm{mg} / \mathrm{kg} / \mathrm{bw} / \mathrm{d}$ of PBO to parents and offspring affected olfactory orientation. These results were later confirmed in a similar study by Tanaka (2003) performed with lower doses. This time prolonged exposure of circa $100 \mathrm{mg} / \mathrm{kg} / \mathrm{bw} / \mathrm{d}$ to parents and offspring resulted in significantly restrained olfactory orientation. Other developmental behavioural effects were manifested in a dose-related manner for males in the F1 generation as male mice showed delayed surface righting (time to right themselves when placed on their backs) (Tanaka 2003).

The above reported findings of Tanaka must have been overlooked by Johri et al., who in a publication from 2006, erroneously stated that:

«there are no reports indicating developmental neurotoxicity of piperonyl

butoxide.»

Epidemiological data on $\mathrm{PBO}$ has been published recently in a study by Horton et al. (2011) that also included exposure data. The neurodevelopment of 3 year old children were examined by studying cognitive and motor development. Children with higher prenatal exposure to piperonyl butoxide $(>4.34 \mathrm{ng} / \mathrm{m} 3)$ scored significantly lower on the mental development index.

For 230 subjects there were data available on PBO in personal air as sampled on the pregnant mother and PBO was detected in $75 \%$ of the samples. Data were adjusted for gender, ethnicity, prenatal smoking exposure, gestational age at birth, maternal nonverbal intelligence, maternal education, and quality of the home environment before statistical analysis. 


\section{Non-mammalian toxicology}

PBO prevented oviposition in ticks (Boophilus microplus) when administered topically to females at the fairly high individual dose of $500 \mu \mathrm{g}$ (Connat et al. 1988). In another study, $100 \mu \mathrm{g}$ of PBO administered topically did not affect the timing of metamorphosis in beetles (Tribolium freemani) (Hirashima et al. 1995).

Exposure of Daphnia magna to $300 \mu \mathrm{g} / \mathrm{l}$ of PBO lead to a strong induction of vitellogenin mRNA (Hannas et al. 2011). Unlike the wellknown causal link for estrogenic induction of vitellogenin in fish, estrogens appear to have little role in regulating vitellogenin mRNA levels in daphnids. Instead it seems that vitellogenin is surpressed by ecdysteroids. Hence, these results do demonstrate an endocrine effect but not an estrogenic one.

\section{Toxicity data}

An overview of toxicity data on possible endocrine effects of piperonyl butoxide is presented in Table 3.3 below. 


\begin{tabular}{|c|c|c|c|c|c|c|c|c|c|}
\hline & Organism & Method & Endpoint & $\begin{array}{c}\text { Possible } \\
\text { endo- } \\
\text { crine } \\
\text { effects }\end{array}$ & LOEC/LOEL/EC5O & NOEL ${ }^{b}$ & $\begin{array}{l}\text { Lowest tested } \\
\text { concentra- } \\
\text { tion/dose } \\
\end{array}$ & $\begin{array}{l}\text { Highest tested } \\
\text { concentra- } \\
\text { tion/dose } \\
\end{array}$ & Reference \\
\hline \multirow{5}{*}{$\stackrel{\stackrel{̊}{\Sigma}}{\Xi}$} & & $\begin{array}{l}\text { H295R steroido- } \\
\text { genesis assay }\end{array}$ & testosterone production & + & $10 \mathrm{mg} / \mathrm{l}(30 \mu \mathrm{M})$ & & $0,001 \mu \mathrm{M}$ & $100 \mu \mathrm{M}$ & $\begin{array}{c}\text { Hecker,M., Hollert,H., Cooper,R., Vinggaard,A.M., } \\
\text { Akahori,Y., Murphy,M., Nellemann,C., Higley,E., } \\
\text { Newsted,J., Laskey,J., Buckalew,A., Grund,S., } \\
\text { Maletz,S., Giesy,J., Timm,G. (2011) }\end{array}$ \\
\hline & murine & $\begin{array}{l}\text { Immunotoxicity, } \\
\text { spleen cell assay }\end{array}$ & apoptosis & + & $55 \mu \mathrm{M}$ & & & & $\begin{array}{l}\text { Battaglia, C., Gogal, R., Zimmerman, K., Misra, H. } \\
(2010)\end{array}$ \\
\hline & $\begin{array}{l}\text { Oncorhynchus } \\
\text { mykiss }\end{array}$ & $\begin{array}{c}\text { trout hepatocyte } \\
\text { assay }\end{array}$ & $\begin{array}{c}\text { enzyme activity } \\
\text { (CYP3A27, progesterone- } \\
6 \beta \text {-hydroxylase) }\end{array}$ & + & $100 \mu \mathrm{M}$ & & $100 \mu \mathrm{M}$ & $100 \mu \mathrm{M}$ & Miranda, C.L., Hendeerson, M.C., Buhler, D.R. (1998) \\
\hline & Rat & $\begin{array}{l}\text { mouse pituitary } \\
\text { tumour cell line }\end{array}$ & $\begin{array}{l}\text { secretagogue-induced } \\
\text { release of corticotropin }\end{array}$ & + & & & & & Luini, A.G., Axelrod, J. (1985) \\
\hline & & $\begin{array}{l}\text { H295R steroido- } \\
\text { genesis assay }\end{array}$ & $\begin{array}{l}\text { 17beta-estradiol produc- } \\
\text { tion }\end{array}$ & - & & $100 \mu \mathrm{M}$ & $0,001 \mu \mathrm{M}$ & $100 \mu \mathrm{M}$ & $\begin{array}{c}\text { Hecker,M., Hollert,H., Cooper,R., Vinggaard,A.M., } \\
\text { Akahori,Y., Murphy,M., Nellemann,C., Higley,E., } \\
\text { Newsted,J., Laskey,J., Buckalew,A., Grund,S., } \\
\text { Maletz,S., Giesy,J., Timm,G. (2011) }\end{array}$ \\
\hline \multirow{6}{*}{ 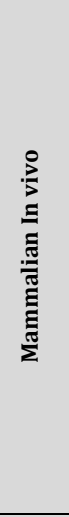 } & Dog & $\begin{array}{l}\text { dog prolonged } \\
\text { oral intake }\end{array}$ & adrenal weight & + & $32 \mathrm{mg} / \mathrm{kg} / \mathrm{bw} / \mathrm{d}$ & $3 \mathrm{mg} / \mathrm{kg} / \mathrm{bw} / \mathrm{d}$ & $3 \mathrm{mg} / \mathrm{kg} / \mathrm{bw} / \mathrm{d}$ & & $\begin{array}{c}\text { National Pesticide Information Center. Oregon State } \\
\text { University. Piperonyl Butoxide } \\
\text { (Technical Fact Sheet) }^{\mathrm{e}} \\
\text { http://npic.orst.edu/factsheets/pbotech.pdf }\end{array}$ \\
\hline & Mouse & $\begin{array}{l}\text { mouse 2- } \\
\text { generation study } \\
\text { dietary exposure }\end{array}$ & $\begin{array}{l}\text { behaviour, olfactory } \\
\text { orientation }\end{array}$ & + & $102^{\mathrm{c}} \mathrm{mg} / \mathrm{kg} / \mathrm{bw} / \mathrm{d}$ & $37^{\mathrm{c}} \mathrm{mg} / \mathrm{kg} / \mathrm{bw} / \mathrm{d}$ & $37^{\mathrm{c}} \mathrm{mg} / \mathrm{kg} / \mathrm{bw} / \mathrm{d}$ & $327^{\mathrm{c}} \mathrm{mg} / \mathrm{kg} / \mathrm{bw} / \mathrm{d}$ & Tanaka, T. (2003) \\
\hline & Mouse & $\begin{array}{c}\text { mouse 2- } \\
\text { generation study } \\
\text { dietary exposure }\end{array}$ & behaviour, motor activity & + & & & & & Tanaka, T. (2003) \\
\hline & Mouse & $\begin{array}{c}\text { mouse 2- } \\
\text { generation study } \\
\text { dietary exposure } \\
\end{array}$ & $\begin{array}{l}\text { behaviour, olfactory } \\
\text { orientation }\end{array}$ & + & $890^{\mathrm{d}} \mathrm{mg} / \mathrm{kg} / \mathrm{bw} / \mathrm{d}$ & $438^{\mathrm{d}} \mathrm{mg} / \mathrm{kg} / \mathrm{bw} / \mathrm{d}$ & $225^{\mathrm{d}} \mathrm{mg} / \mathrm{kg} / \mathrm{bw} / \mathrm{d}$ & $890^{\mathrm{d}} \mathrm{mg} / \mathrm{kg} / \mathrm{bw} / \mathrm{d}$ & Tanaka, T. (1992) \\
\hline & Mouse & $\begin{array}{c}\text { repeated oral } \\
\text { dose for } 7 \text { weeks }\end{array}$ & behaviour, motor activity & + & $438^{\mathrm{C}} \mathrm{mg} / \mathrm{kg} / \mathrm{bw} / \mathrm{d}$ & $225^{\mathrm{c}} \mathrm{mg} / \mathrm{kg} / \mathrm{bw} / \mathrm{d}$ & $225^{\mathrm{c}} \mathrm{mg} / \mathrm{kg} / \mathrm{bw} / \mathrm{d}$ & $890^{\mathrm{C}} \mathrm{mg} / \mathrm{kg} / \mathrm{bw} / \mathrm{d}$ & Tanaka, T. (1993) \\
\hline & Rat & pituitary study & $\begin{array}{l}\text { secretagogue-induced } \\
\text { release of corticotropin }\end{array}$ & + & & & & & Okajima,T., Hertting, G. (1986) \\
\hline \multirow{4}{*}{ 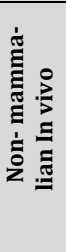 } & $\begin{array}{l}\text { Anas platyrhyn- } \\
\text { chos }\end{array}$ & $\begin{array}{l}\text { avian reproduc- } \\
\text { tion } \\
\end{array}$ & egg shell thickness & + & $1200 \mathrm{ppm}$ & 300 ppm & & & $\operatorname{EPA} \operatorname{RED}(2006)^{\mathrm{e}}$ \\
\hline & Daphnia magna & $\begin{array}{c}\text { Daphnia vitello- } \\
\text { genesis }\end{array}$ & vitellogenin & + & $300 \mu \mathrm{g} / \mathrm{l}$ & & $300 \mu \mathrm{g} / \mathrm{l}$ & & $\begin{array}{c}\text { Hannas, B., Wang, Y., Thomson, S., Kwon, G., Li, H., } \\
\text { LeBlanc, G. (2011) }\end{array}$ \\
\hline & Tribolium freeman & $\begin{array}{c}\text { insect topical } \\
\text { treatment }\end{array}$ & metamorphosis & - & & $100 \mu \mathrm{g} /$ insect & & $100 \mu \mathrm{g} /$ insect & Hirashima, A., Takeya, R.,Taniguchi, E.,Eto, M. (1995) \\
\hline & $\begin{array}{l}\text { Boophilus mi- } \\
\text { croplus }\end{array}$ & $\begin{array}{l}\text { insect topical } \\
\text { treatment }\end{array}$ & $\begin{array}{l}\text { oviposition and egg } \\
\text { viability }\end{array}$ & + & $500 \mu \mathrm{g} /$ insect & $100 \mu \mathrm{g} /$ insect & $100 \mu \mathrm{g} /$ insect & & Connat, J-L. (1988) \\
\hline
\end{tabular}

a The qualitative result of the study was evaluated as described in section 2.3 above.

$\mathrm{b}$ NOEL was only registered when authors used this terminology or in cases where data on effects at higher concentration was presented.

${ }^{c}$ Approximated median dose, ${ }^{\text {d }}$ Approximated median dose based on information from similar study by Tanaka (1993). ${ }^{\text {e }}$ The source is a report and not a peer-reviewed paper. 


\subsection{Resorcinol}

Resorcinol is an antiseptic used in ointments e.g. for treatment of psoriasis or acne. Resorcinol is an industrial chemical. The resorcinol moiety has been found in a wide variety of natural products.

Resorcinol has the following harmonized classification:

- Acute Tox. 4 - Harmful if swallowed

- Skin Irrit. 2 - Causes skin irritation

- Eye Irrit. 2 - Causes serious eye irritation

- Aquatic Acute 1 - Very toxic to aquatic life

(Source: European Chemicals Agency, http://echa.europa.eu/)

\section{Data review}

Resorcinol is a known thyroid peroxidase inhibitor (Lutz et al. 2005). The scientific evidence for endocrine disrupting effects has been evaluated by the Danish Centre on Endocrine Disrupters (CEHOS 2012) according to standards and criteria stated in the Danish proposal to the ongoing EU-process for criteria setting (Danish Ministry of the Environment, 2011). CEHOS categorized resorcinol as an endocrine disrupter in Category 1.

There are several human case reports from 1950 to 1977 that clearly demonstrates the anti-thyroid functions of resorcinol as reviewed by Lynch et al. (2002). Pathological case reports are of course very valuable in the overall evaluation of chemicals but the scope of the present review is on methods within the regulatory framework (OECD CF) and therefore only in vitro and in vivo studies are discussed.

\section{In vitro studies}

Thyroid peroxidase catalyses the addition of iodine into thyroxine (T4) or triiodothyronine (T3) and is therefore a crucial enzyme for the production of thyroid hormones. In vitro assays with thyroid slices have demonstrated that resorcinol inhibits thyroid peroxidase Lindsay et al. (1992).

Additional, endocrine effects of resorcinol have been demonstrated in other in vitro assays (Waring et al. 2012). At a LOEC of $10 \mu \mathrm{M}$ the effects 
included both non-genomic influence demonstrated as effects on aromatase $^{16}$ activity in human choricarcinoma cells, and genomic influence demonstrated as a direct effect on the Thyroid Receptor in a T-Screen Assay with rat pituitary (GH3) cell line. A similar activity of $50 \mu \mathrm{M} \mathrm{LOEC}$ for resorcinol in a T-Screen Assay was observed by Ghisari et al. (2009). The effect of resorcinol on a thyroid cancer cell line (F9 embryonal) was tested by Kang et al. (2011). Anti-thyroid effects were in this in vitro assay shown as an inhibition of cell proliferation. At a concentration of $100 \mu \mathrm{M}$ there was a slight but statistical inhibition but no effects were observed for resorcinol at lower concentrations. An alternative mechanism for endocrine effects of resorcinol was tested by Turan et al. (2005). Sulphation of thyroid hormones renders them inactive and chemicals interfering with this enzymatic mechanism are potential endocrine disruptors. Resorcinol did not modulate the expression of enzymes important for the sulphation at a concentration from $0.005 \mu \mathrm{M}$ to $0.5 \mu \mathrm{M}$.

There were no signs of estrogenic activity of resorcinol when tested in an estrogen receptor transactivation assay (human breast cancer cell line MCF-7) by Ghisari et al. (2009). Saito et al. (1999) did not find estrogenic activity, neither in a yeast estrogen screen, nor in a mammalian cell-based assay at a maximum concentration of $1 \mathrm{mg} / \mathrm{l}$.

In vitro experiments with rat pituitary GH3 cells showed that resorcinol had thyroid hormone-like effects by stimulation the proliferation of cells with a LOEC of $50 \mathrm{mM}$ (Ghisari 2009). In contrast to other chemicals (e.g. phthalates) tested in the same study, resorcinol did not result in concentration-response curves that allowed the calculation of EC50 values. In another in vitro experiment resorcinol inhibited cell differentiation of mouse embryonal carcinoma cells at a concentration of $100 \mu \mathrm{M}$ but not at lower concentrations (Kang et al. 2011). Resorcinol is a weak antagonist for AR with an IC50 of 2,9x10-5 in comparison with ARantagonistic standard hydroxyflutamide (Krüger et al. 2008).

\section{Mammalian toxicology}

The effect of resorcinol on thyroid uptake of iodine was studied in rats (Arnott and Doniach, 1952). After a subcutaneous injection of the chemical and radioactive iodine it was found that uptake was reduced to $11 \%$

\footnotetext{
16 Waring refers to the aromatase activity as being related to CYP2C19. This is odd since 5 -alfa-reductase is normally the enzymatic activity that is said to relate to CYP2C19! For method description Waring refers to Drenth et al. 1998 who describes a method for aromatase activity related to CYP19 which makes sence.
} 
of that in the control group. The lowest tested individual dose was 70 $\mathrm{mg} / \mathrm{kg}$.

Most of the in vivo studies commented in the evaluation by CEHOS (see beginning of section above) are studies where rodents have been exposed to rather high concentrations of resorcinol. In a review by Lynch et al. (2002), it is pointed out that anti-thyroid activity of resorcinol is only demonstrated when the chemical is administered in a form where exposure is continuous, such as in the diet, in drinking water, by subcutaneous injection in an oil-based vehicle, or by repeated dermal application. In these older studies (performed before 1985) with rodents, commented by Lynch, the endpoint studied was mostly thyroid weight or histological effects on thyroid.

Two studies with rats have shown that prolonged ( $>1$ month) exposure of $5 \mathrm{mg} / \mathrm{kg} / \mathrm{bw} / \mathrm{d}$ of resorcinol through drinking water causes histomorphological changes (Seffner et al. 1995) or enlargement (Cooksey et al. 1985) of the thyroid. In the study by Seffner et al. effects were also evident as decreased thyroid-hormone levels in the test animals. In contradiction to this, no effects on thyroid hormone levels or other significant thyroid histological effects were observed in a study where rats received resorcinol by gavage in concentrations ranging from 32 to 520 $\mathrm{mg} / \mathrm{kg} / \mathrm{bw} / \mathrm{d}$ (NTP 1992).

Welsch et al. (2008) performed a study according to TG 416 where the maximum daily dose for $\mathrm{F}_{0}$ and $\mathrm{F}_{1}$ rats were $233 \mathrm{mg} / \mathrm{bw} / \mathrm{d}$ in males, $304 \mathrm{mg} / \mathrm{bw} / \mathrm{d}$ in premating/gestation females and $660 \mathrm{mg} / \mathrm{bw} / \mathrm{d}$ in lactating females. It was concluded that males were more susceptible and histopathological effects on thyroid gland caused by resorcinol were confirmed in $\mathrm{F}_{0}$ males. However, the effects were considered as an adaptive thyroid response to a new homeostatic level and not as adverse effects.

\section{Non-mammalian toxicology}

Only one study for non-mammalian testing of endocrine effects of resorcinol was found. Thienpont et al. (2011) exposed zebra fish (Dania rerio) embryos to resorcinol which resulted in significant decrease of intrafollicular thyroid hormone levels.

\section{Toxicity data}

An overview of toxicity data on possible endocrine effects of resorcinol is presented in Table 3.4 below. 
Table 3.4 Overview of toxicity data on possible endocrine effects of resorcinol

\begin{tabular}{|c|c|c|c|c|c|c|c|c|c|}
\hline & Organism & Method & Endpoint & $\begin{array}{c}\text { Possible endocrine } \\
\text { effects }^{\mathrm{a}}\end{array}$ & LOEC/LOEL/EC5O & NOEL ${ }^{b}$ & $\begin{array}{c}\text { Lowest tested } \\
\text { concentration/dose }\end{array}$ & $\begin{array}{c}\text { Highest tested } \\
\text { concentration/dose }\end{array}$ & Reference \\
\hline \multirow{9}{*}{ 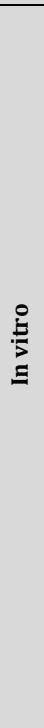 } & & thyroid slice system & $\begin{array}{l}\text { Thyroid } \\
\text { peroxidase } \\
\text { activity }\end{array}$ & + & & & & & $\begin{array}{l}\text { Lindsay, R.H., Hill, J.B., Gaitan, E., Cooksey, R.C., } \\
\text { and Jolley, R.L., } 1992 .\end{array}$ \\
\hline & & $\begin{array}{l}\text { rat pituitary TH-dependent GH3 } \\
\text { cell proliferation (T-screen) }\end{array}$ & $\begin{array}{l}\text { cell prolif- } \\
\text { eration }\end{array}$ & + & $10 \mu \mathrm{M}$ & & & & $\begin{array}{l}\text { Waring, R. H., Ramsden, D. B., Jarratt, P. D. B., } \\
\text { Harris, R. M. (2012) }\end{array}$ \\
\hline & & $\begin{array}{l}\text { rat pituitary TH-dependent GH3 } \\
\text { cell proliferation (T-screen) }\end{array}$ & $\begin{array}{l}\text { cell prolif- } \\
\text { eration }\end{array}$ & + & $50 \mu \mathrm{M}$ & & $0,1 \mathrm{nM}$ & $50 \mu \mathrm{M}$ & Ghisari, M., Bonefeld-Jorgensen, E. (2009) \\
\hline & & $\begin{array}{l}\text { human charocarcinoma aroma- } \\
\text { tase assay }\end{array}$ & $\begin{array}{c}\text { aromatase } \\
\text { activity }\end{array}$ & + & $10 \mu \mathrm{M}$ & & & & $\begin{array}{l}\text { Waring, R. H., Ramsden, D. B., Jarratt, P. D. B., } \\
\text { Harris, R. M. (2012) }\end{array}$ \\
\hline & & $\begin{array}{l}\text { mouse embryonal carcinoma cell } \\
\text { differentiation }\end{array}$ & $\begin{array}{l}\text { carcinoma } \\
\text { cell differ- } \\
\text { entiation }\end{array}$ & + & $100 \mu \mathrm{M}$ & & $1 \mu \mathrm{M}$ & $100 \mu \mathrm{M}$ & Kang, H., Youn, Y., Hong, M., Kim, L. (2011) \\
\hline & & $\begin{array}{l}\text { human breast cancer MCF-7 cell } \\
\text { proliferation }\end{array}$ & $\begin{array}{c}\text { gene } \\
\text { expression }\end{array}$ & - & & & $0,1 \mathrm{nM}$ & $50 \mu \mathrm{M}$ & Ghisari, M., Bonefeld-Jorgensen, E. (2009) \\
\hline & & $\begin{array}{l}\text { mammalian cell-based luciferase } \\
\text { reporter gene assay }\end{array}$ & $\begin{array}{l}\text { gene } \\
\text { transcrip- } \\
\text { tion }\end{array}$ & - & & & $0,11 \mu \mathrm{g} / \mathrm{l}$ & $1101 \mu \mathrm{g} / \mathrm{l}$ & Saito K, Isobe N, Kaneko H, Nakatsuka I (1999) \\
\hline & & $\begin{array}{c}\text { cell test for steroid and thyroid } \\
\text { hormones synthesis, metabolism } \\
\text { and transportation }\end{array}$ & $\begin{array}{l}\text { mRNA } \\
\text { levels }\end{array}$ & - & & & $0,005 \mu \mathrm{M}$ & $0,5 \mu \mathrm{M}$ & Turan, N., Waring, R.H., Ramsden, D.B. (2005) \\
\hline & & YES & $\begin{array}{l}\text { ER binding / } \\
\text { gene } \\
\text { transcrip- } \\
\text { tion }\end{array}$ & - & & & & & Saito K, Isobe N, Kaneko H, Nakatsuka I (1999) \\
\hline
\end{tabular}

a The qualitative result of the study was evaluated as described in section 2.3 above.

b NOEL was only registered when authors used this terminology or in cases where data on effects at higher concentration was presented. 
Table 3.4 continued Overview of toxicity data on possible endocrine effects of resorcinol

\begin{tabular}{|c|c|c|c|c|c|c|c|c|c|}
\hline & Organism & Method & Endpoint & $\begin{array}{c}\text { Possible } \\
\text { endocrine } \\
\text { effects }^{\text {a }}\end{array}$ & LOEC/LOEL/EC50 & NOEL ${ }^{b}$ & $\begin{array}{l}\text { Lowest tested } \\
\text { concentration/dose }\end{array}$ & $\begin{array}{c}\text { Highest } \\
\text { tested } \\
\text { concentra- } \\
\text { tion/dose } \\
\end{array}$ & Reference \\
\hline \multirow{17}{*}{ 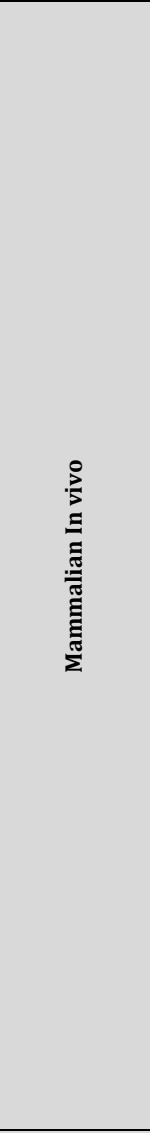 } & Rat & $\begin{array}{c}\text { repeated subcutaneous injection } \\
\text { with oil }\end{array}$ & thyroid weight & + & & $\begin{array}{c}154 \\
\mathrm{mg} / \mathrm{kg} / \mathrm{bw} / \mathrm{d}\end{array}$ & & $\begin{array}{c}308 \\
\mathrm{mg} / \mathrm{kg} / \mathrm{bw} / \mathrm{d}\end{array}$ & Doniach, I., and Logothetopoulos, J. (1953) \\
\hline & $\begin{array}{l}\text { Hooded } \\
\text { Lister rat }\end{array}$ & repeated subcutaneous injection & $\begin{array}{l}\text { thyroid iodine } \\
\text { uptake }\end{array}$ & + & & & & $\begin{array}{c}1 \\
\mathrm{mg} / \mathrm{kg} / \mathrm{bw} / ?\end{array}$ & Doniach, I., Fraser. R. (1950) \\
\hline & Rat & single subcutaneous injection & $\begin{array}{l}\text { thyroid iodine } \\
\text { uptake }\end{array}$ & + & & & $70 \mathrm{mg} / \mathrm{kg} / \mathrm{bw}$ & $\begin{array}{c}180 \\
\mathrm{mg} / \mathrm{kg} / \mathrm{bw}\end{array}$ & Arnott, D.G., Doniach, I. (1952) \\
\hline & Rat & repeated oral dose & $\begin{array}{c}\text { hormone concentra- } \\
\text { tion }\end{array}$ & + & & & $5 \mathrm{mg} / \mathrm{kg} / \mathrm{bw} / \mathrm{d}$ & & $\begin{array}{l}\text { Cooksey, R. C., Gaitan, E., Lindsay, R. H., } \\
\text { Hill, J. B., and Kelly, K. (1985) }\end{array}$ \\
\hline & Rat & repeated oral dose & thyroid, histological & + & & & $5 \mathrm{mg} / \mathrm{kg} / \mathrm{bw} / \mathrm{d}$ & $\begin{array}{c}10 \\
\mathrm{mg} / \mathrm{kg} / \mathrm{bw} / \mathrm{d}\end{array}$ & $\begin{array}{c}\text { Seffner, W., Schiller, F., Heinze, R., Breng, } \\
\text { R. (1995) }\end{array}$ \\
\hline & Rat & repeated oral dose & thyroid weight & + & & & $5 \mathrm{mg} / \mathrm{kg} / \mathrm{bw} / \mathrm{d}$ & $\begin{array}{c}10 \\
\mathrm{mg} / \mathrm{kg} / \mathrm{bw} / \mathrm{d}\end{array}$ & $\begin{array}{l}\text { Cooksey, R. C., Gaitan, E., Lindsay, R. H., } \\
\text { Hill, J. B., and Kelly, K. (1985) }\end{array}$ \\
\hline & $\begin{array}{c}\text { Sprague- } \\
\text { Dawley rat }\end{array}$ & $\begin{array}{l}\text { TG } 416 \text { 2-generation reproduction } \\
\text { toxicity study (most recent update) }\end{array}$ & thyroid, histological & Inc. ${ }^{e}$ & $233 \mathrm{mg} / \mathrm{kg} / \mathrm{bw} / \mathrm{d}$ & $\begin{array}{c}86 \\
\mathrm{mg} / \mathrm{kg} / \mathrm{bw} / \mathrm{d}\end{array}$ & $11 \mathrm{mg} / \mathrm{kg} / \mathrm{bw} / \mathrm{d}$ & $\begin{array}{c}233 \\
\mathrm{mg} / \mathrm{kg} / \mathrm{bw} / \mathrm{d}\end{array}$ & $\begin{array}{l}\text { Welsch, F., Nemec, M.D., and Lawrence, } \\
\text { W.B. (2008) }\end{array}$ \\
\hline & Rat & repeated oral dose & thyroid weight & + & $3750 \mathrm{mg} / \mathrm{kg} / \mathrm{bw} / \mathrm{d}$ & & & $\begin{array}{c}3750 \\
\mathrm{mg} / \mathrm{kg} / \mathrm{bw} / \mathrm{d}\end{array}$ & $\begin{array}{l}\text { Berthezene, F., Perrot, L., Munari, Y., and } \\
\text { Ponsin, G. (1979) }\end{array}$ \\
\hline & Rat & $\begin{array}{l}\text { repeated subcutaneous injection } \\
\text { with oil }\end{array}$ & thyroid weight & + & $400 \mathrm{mg} / \mathrm{kg} / \mathrm{bw} / \mathrm{d}$ & & & $\begin{array}{c}400 \\
\mathrm{mg} / \mathrm{kg} / \mathrm{bw} / \mathrm{d}\end{array}$ & Samuel, K.C. (1955) \\
\hline & Rat & $\begin{array}{l}\text { repeated subcutaneous injection } \\
\text { with oil }\end{array}$ & thyroid, histological & + & $750 \mathrm{mg} / \mathrm{kg} / \mathrm{bw} / \mathrm{d}$ & & & & Samuel, K.C. (1955) \\
\hline & Mouse & mouse repeated oral dose & $\begin{array}{c}\text { thyroid effects } \\
\text { (details not stated) }\end{array}$ & - & & & $28 \mathrm{mg} / \mathrm{kg} / \mathrm{bw} / \mathrm{d}$ & $\begin{array}{c}130 \\
\mathrm{mg} / \mathrm{kg} / \mathrm{bw} / \mathrm{d}\end{array}$ & National Toxicology Program (NTP) (1992) ${ }^{\mathrm{d}}$ \\
\hline & Rat & repeated dermal exposure & $\begin{array}{c}\text { thyroid effects } \\
\text { (details not stated) }\end{array}$ & - & & & & $\begin{array}{c}300 \\
\mathrm{mg} / \mathrm{kg} / \mathrm{bw} / \mathrm{d}\end{array}$ & Doniach, I., and Logothetopoulos, J. (1953) \\
\hline & Rat & repeated subcutaneous injection & $\begin{array}{c}\text { thyroid effects } \\
\text { (details not stated) }\end{array}$ & - & & $\begin{array}{c}50 \\
\mathrm{mg} / \mathrm{kg} / \mathrm{bw} / \mathrm{d}\end{array}$ & & $\begin{array}{c}50 \\
\mathrm{mg} / \mathrm{kg} / \mathrm{bw} / \mathrm{d}\end{array}$ & $\begin{array}{l}\text { Cheymol, J., Gay, Y., and Laveden, J. P. } \\
\text { (1951) }\end{array}$ \\
\hline & Rabbit & repeated subcutaneous injection & $\begin{array}{c}\text { thyroid effects } \\
\text { (details not stated) }\end{array}$ & - & & $\begin{array}{c}75 \\
\mathrm{mg} / \mathrm{kg} / \mathrm{bw} / \mathrm{d}\end{array}$ & & & Klein, F., Ottis, V., and Velvart, J. (1950) \\
\hline & Rat & repeated oral dose & $\begin{array}{c}\text { thyroid effects } \\
\text { (details not stated) }\end{array}$ & - & & & $32 \mathrm{mg} / \mathrm{kg} / \mathrm{bw} / \mathrm{d}$ & $\begin{array}{c}130 \\
\mathrm{mg} / \mathrm{kg} / \mathrm{bw} / \mathrm{d}\end{array}$ & National Toxicology Program (NTP) (1992) \\
\hline & $\begin{array}{l}\text { Sprague- } \\
\text { Dawley rat }\end{array}$ & $\begin{array}{l}\text { TG } 416 \text { 2-generation reproduction } \\
\text { toxicity study (most recent update) }\end{array}$ & $\begin{array}{c}\text { thyroid weight, } \\
\text { histological, hor- } \\
\text { mone concentration } \\
\text { (females) }\end{array}$ & - & & $\begin{array}{c}660 \\
\mathrm{mg} / \mathrm{kg} / \mathrm{bw} / \mathrm{d}\end{array}$ & $16 \mathrm{mg} / \mathrm{kg} / \mathrm{bw} / \mathrm{d}$ & $\begin{array}{c}660 \\
\mathrm{mg} / \mathrm{kg} / \mathrm{bw} / \mathrm{d}\end{array}$ & $\begin{array}{l}\text { Welsch, F., Nemec, M.D., and Lawrence, } \\
\text { W.B. (2008) }\end{array}$ \\
\hline & $\begin{array}{l}\text { Sprague- } \\
\text { Dawley rat }\end{array}$ & $\begin{array}{l}\text { TG } 416 \text { 2-generation reproduction } \\
\text { toxicity study (most recent update) }\end{array}$ & $\begin{array}{c}\text { thyroid weight, } \\
\text { hormone concentra- } \\
\text { tion (males) } \\
\end{array}$ & - & & $\begin{array}{c}233 \\
\mathrm{mg} / \mathrm{kg} / \mathrm{bw} / \mathrm{d}\end{array}$ & $11 \mathrm{mg} / \mathrm{kg} / \mathrm{bw} / \mathrm{d}$ & $\begin{array}{c}233 \\
\mathrm{mg} / \mathrm{kg} / \mathrm{bw} / \mathrm{d}\end{array}$ & $\begin{array}{l}\text { Welsch, F., Nemec, M.D., and Lawrence, } \\
\text { W.B. (2008) }\end{array}$ \\
\hline $\begin{array}{c}\text { Non- } \\
\text { mammalian } \\
\text { In vivo }\end{array}$ & Danio rerio & zebrafish embryo 3 days exposure ${ }^{c}$ & $\begin{array}{l}\text { hormone concentra- } \\
\text { tion }\end{array}$ & + & EC50 $120 \mu \mathrm{M}$ & & & & $\begin{array}{l}\text { Thienpont, B., Tingaud-Sequeira, A., Prats, } \\
\text { E., Barata, C., Babin, P., Raldua, D. (2011) }\end{array}$ \\
\hline
\end{tabular}

a The qualitative result of the study was evaluated as described in section 2.3 above.

b NOEL was only registered when authors used this terminology or in cases where data on effects at higher concentration was presented

c CEHOS (2012) states that his study could be viewed as an in vitro study due to the EU legislation about fish embryos

${ }^{d}$ The source is a report and not a peer reviewed paper

e Adaptive thyroid response in $\mathrm{F}_{0}$ males confirmed by histopathology but not considered as adverse effects. 


\section{Discussion}

\subsection{Diuron}

\section{Weight of evidence and comments on the reviewed studies}

A varied material of scientific publications on possible endocrine effects of diuron was retrieved, encompassing many different types of test methods. The reviewed studies demonstrate endocrine effects relevant for both human- and ecotoxicological concern.

Considering the in vitro studies alone, the reviewed studies are not unanimous. The mechanism of action for ED effects of diuron may be both through the direct action on nuclear hormone receptors and through the action on steroidogenesis.

In vitro studies with diuron showed an antagonistic interaction with both estrogen receptor and androgen receptor in yeast assays (YES) (Orton et al. 2009). The same publication also showed that diuron had an impact on steroid hormone metabolism in an oocyte cell assay. The impact of diuron on steroid metabolism could be through the direct action on hormone receptors or possibly through activation/inhibition of enzymes important in the steroidogenesis.

Enzymes of the CytochromeP450-family are important for the regulation of steroid hormones. Diuron did not have any effect on aromatase activity (CYP19) when tested, with a human placental cell assay (Vinggaard et al. 2000, with rainbow trout brain aromatase assay (Hinfray et al. 2006) or with rainbow trout ovary aromatase assay (Hinfray et al. 2006). Diuron did not have any effect on 5alpha reductase (CYP2) when tested with a human prostate cell assay (Lo et al. 2007).

CYP1A induction of diuron has been shown both in vitro (Marco et al. 2012) and in vivo (Takeuchi 2008). This is thought to be via the direct binding of diuron to AhR and activation of the AhR signalling pathway.

Evidence from in vitro studies altogether indicates that diuron affects steroidogenesis but the mechanism is unclear. The AhR activity of diuron demonstrates a possible mechanism for indirect endocrine effects. However, it is primarily other enzymes than CYP1A1 in the CytochromeP450-family that are of importance for regulation of steroid 
hormones. (See discussion on different P450 enzymes and piperonyl butoxide below).

Diuron has reproductive toxicological effects on female physiology as indicated by effects on ovaries in rats exposed in utero (Grassi et al. 2011). It can be argued that since this study failed to reveal effects on circulating hormone levels this study did only indicate reproductive toxicological effects and not endocrine disruption ${ }^{17}$. On the other hand, systematic endocrine effects are indeed plausible secondary effects of diuron since the physiological effects demonstrated by Grassi et al. (2011) involved the corpora lutea.

A clear case of endocrine disruption was demonstrated by both physiological effects and effect on hormone levels in lizard (Cardone et al. 2008). In this study diuron had reproductive toxicological effects on testis as well as on serum levels of testosterone. This study also contributes with important information regarding alternative mechanisms of endocrine disruption of diuron since it is suggested that some effects are related to the degradation product of diuron. The unusual route of exposure, through contaminated soil in aquaria and/or food and water, makes it difficult to compare the actual dose administered in relation to other studies. However, the study simulated environmental exposure scenarios in a relevant way with relevant concentrations.

The reviewed literature regarding non mammalian studies demonstrates endocrine effects on fish, amphibians, mollusc, shrimp and springtail.

Diuron has reproductive toxicological effects on fish as indicated by abnormal or dead fry (Call et al. 1987). Behavioural effects of diuron on fish have been indicated by Saglio et al. (1998) but in this study the statistical data is not very solid.

Several experiments with invertebrates have shown that diuron has physiological effects that may be caused by endocrine disruption. However the endocrine systems of these organisms are poorly investigated and hence these effects cannot be taken as proof of diuron acting as an EDC. Diuron causes adverse effects on oysters including effects on spermatozoa (Akacha et al. 2012), effects on the reproductive cycle (Buisson et al. 2008) and immunological effects (Luna-Acosta et al. 2012). Diuron

\footnotetext{
17 In a strict sence the effects on hormone productive organs, such as testis or ovaries, are not regarded as proof of endocrine disruption. Only when hormone levels or secretory cells are affected are the effects considered as proof of endocrine disruption. In a regulatory evaluation of a suspcected EDC the complete data material is evaluated in order to draw conclusions based on mechanistic proof of endocrine disruption. Within the context of the current report no distinction is made between the two types of results when comparing e.g. the sensitivity of different assays and experimental methods. In this report all effects on hormone productive organs are considered as an endocrine effect.
} 
has reproductive effects on springtail (Campriche et al. 2006) and shrimp (Turner 2003). Diuron affects the metamorphosis of corals (Negri et al. 2005).

\section{Comparison with OECD CF methods}

The in vitro methods YES and YAS, that demonstrated action of diuron on ER and AR respectively, are methods that are very commonly used. However, they have not been included in the OECD guidance since they suffer from limitations such as problems with compounds that have fungicidal activity or in other ways interfere with the cell assay (OECD 2012, page 29). The anti-estrogenic action demonstrated by Orton et al. (2009) speaks against what has been stated elsewhere about the YES assay not being sensitive for anti-estrogenic chemicals (Fang et al., 2000). Orton et al. (2009) also demonstrated in vitro effects of diuron on steroidogenesis with a frog oocyte cell assay. OECD TG 456: H295R Steroidogenesis Assay utilises a human adrenocarcinoma cell line and it is not certain that diuron would have an effect on this cell line.

OECD TG 416 and TG 443 involve exposure of pregnant rodents, $F_{1}$ offspring and pregnant $F_{1}$ generation. The latter of the two standardized methods incorporates measurement of hormone levels. The study by Grassi et al. (2011) incorporated the measurement of LH and FSH serum levels and therefore was more similar to TG 443. The additional information from hormone analysis did not make the animal experiment more sensitive towards discovering the adverse effects of diuron. While negative effects on ovaries were found the hormone levels were still normal. From this the authors concluded that diuron caused reproductive toxicity but not necessary systematic endocrine disruption.

- TG 416 and TG 443 are equally sensitive and adequate for evaluation of diuron but TG 443 adds to a better understanding of the systematic effect of the test chemical.

In the study by Fernandes et al. in 2007 adult male rats were exposed to diuron during 30 days. The study is similar to OECD TG 407, Repeated dose 28-day study. The study by Fernandes et al. in 2012 is more similar to TG 416 since both pregnant rats and male offspring were exposed to diuron. Both studies by Fernandes focused on endpoints of male reproductive toxicity and the only indication of adverse effects were the reduction of number of pups in the older study (2007) and reduced body weight of offspring in the later study (2012). The later study used higher 
daily doses of diuron and also included exposure to offspring. From this it can be concluded that expanding the study into the $F_{1}$ generation did not increase the sensitivity as long as the endpoints studied were male reproductive organs.

If only the studies on rats mentioned above are considered, they indicate predominantly estrogenic effects of diuron. If a study with rats and diuron were to be conducted in more strict coherence with TG 407, TG 408 or TG 416, endpoints of both male and female reproductive organs would be included in the protocol. Therefore, all these methods have the potential to reveal reproductive toxicity / endocrine effects of diuron. TG 408 might be more sensitive due to the longer exposure (90 days).

- TG 407 and TG 408 is adequate for evaluation of diuron

If the effects of diuron on both rats (Fernandes et al. 2007, Fernandes et al. 2012, Grassi et al. 2011) and lizard (Cardone et al. 2008) are considered, it seems that diuron may have both estrogenic- and androgenic effects on animals.

- Regardless the choice of standardised OECD method used to study the effects of diuron it is important to include both "male-" and "female-" endpoints

Two TGs with molluscs are currently being developed by the OECD but are not yet available.

- Mollusc Partial Lifecycle Assays, level 4 at the OECD CF

- Mollusc Full Lifecycle Assays, level 5 at the OECD CF

The use of molluscs (oyster) in the study design by Buisson et al. (2008) was a very sensitive test method that could demonstrate effects on spawning at concentrations four times above the environmental concentration $(0.25 \mu \mathrm{g} / \mathrm{l})$ detected in the same study. However, stimulation of spawning is common among aquatic organisms when they are transferred to experimental conditions and therefore this endpoint might easily generate false positives (Buisson et al. 2008). In another study with oyster the relative expression of seven immune-related genes was an equally sensitive endpoint to study the effects of diuron on mollusc (Luna-Acosta et al. 2012). Even more sensitive was the study design set up by Akcha et al. (2012) where embryo-larval development of oysters were significantly affected by diuron at a concentration of $0.05 \mu \mathrm{g} / \mathrm{l}$. 
USEPA has published methods for measuring larval development in oyster (Chapman et. al 1995). The most promising mollusc species that are more likely to within the near future being fully incorporated into the OECD CF is the brackish-water mesogastropod Potamopyrgus antipodarum for the partial life cycle test (Level 4) and the freshwater pulmonate gastropod Lymnaea stagnalis for full life cycle test (Level 5) (Matthiessen 2008).

- Assays with mollusc are adequate and sensitive for evaluation of diuron

- OECD TGs with mollusc are presently being standardized. From the reviewed material it could not be concluded wheather these future assays would capture the endocrine effects of diuron.

Two published studies demonstrated possible endocrine effects in fish exposed to diuron. Behaviour was the endpoint that (maybe) ${ }^{18}$ demonstrated an effect in the study by Saglio and Trijasse (1998) and this is not an endpoint recommended in any of the OECD TGs for fish. Fry development was the endpoint that demonstrated an effect in the study by Call et al. (1987). The species used (fathead minnow) and the experimental set up in this study (exposure to developing fry) is similar to the OECD TG 234 Fish Sexual Development Test.

- OECD TG 234 is adequate for the evaluation of diuron

In the review by Turner (2003) results were presented that indicated effects by diuron in low concentration $(0.56 \mu \mathrm{g} / \mathrm{l})$ on the marine mysid Americamysis bahia. A standardized test (TG for Mysid Lifecycle Test at Level 5 of the OECD CF) is currently being developed that includes the use of Americamysis bahia and Amphiascus tenuiremis as test organisms. Unfortunately the original publication could not be located for a more detailed comparison with this TG but information extracted from a database (EPA OPP database, 2012) revealed that the study indeed had considered reproductive toxicological endpoints such as egghatch and number of live embryos in a life cycle study for 28 days.

- OECD TG for Mysid Lifecycle Test (under development) are adequate and sensitive for the evaluation of diuron

${ }^{18}$ Not very solid statistical material 


\subsection{Piperonyl butoxide}

\section{Weight of evidence and comments on the reviewed studies}

Fewer scientific publications on possible endocrine effects of PBO were found in comparison to diuron. The reviewed studies demonstrate endocrine effects relevant for both human- and ecotoxicological concern.

In vitro studies have demonstrated that $\mathrm{PBO}$ affects steroidogenesis (Hecker et al. 2011). Non EATS-modalities were also demonstrated in vitro as PBO showed immunotoxicity (Battaglia et al. 2010) and a negative effect on the release of corticotropin (Luini and Axelrod 1985).

Epidemiological data is difficult to assess. PBO may have neurological effects on the development of small children. This was indicated by epidemiological data where pregnant mothers had been exposed to PBO via air in their homes (Horton et al. 2011). It may be that very few of the published epidemiological studies have the statistical solidity that enables conclusion on possible endocrine effects. The solidity of the study by Horton et al. (2011) was not evaluated. The causality in epidemiological studies can be evaluated e.g. with the Bradford Hill criteria enlisted in the report by Kortenkamp et al. (2011). Data from human exposure and epidemiological data is of value for the overall evaluation of possible endocrine effects as stated in the report State of the Art Assessment of Endocrine Disrupters:

«Until better tests become available, hazard and risk identification has to rely also on epidemiological approaches.»

(Kortenkamp et. al. 2011)

Laboratory studies indicated developmental behavioural effects of PBO on mouse and rat as shown by Tanaka in three different studies (1992, 1993 and 2003).

The inhibitory effect of PBO on the release of corticotropin that was demonstrated in vitro by Luini and Axelrod (1985) has also been demonstrated in vivo in a study by Okajima and Hertting (1986) on the pituitary of rats.

PBO have reproductive toxicological effects (Connat 1988) and endocrine effects (Hannas et al. 2011) on non-vertebrates. 


\section{Discussion and Comparison with OECD CF methods}

Hecker et al. (2011) used the H295R Steroidogenesis Assay to demonstrate that PBO has a negative effect on the production of testosterone but seemingly no effect on the production of 17beta-estradiol. This method is equal to the OECD TG 456. The cell line used in OECD TG 456 expresses all the key enzymes involved in steroidogenesis. Therefore this assay will not provide specific information on what enzymes that PBO inhibits.

- OECD TG 456 in vitro method is adequate for testing of PBO

- OECD TG 456 in vitro method does not provide specific information on which enzymatic reactions that are effected by PBO

With a mouse pituitary tumour cell line, Luini and Axelrod (1985), demonstrated possible indirect effects of PBO on the corticosteroid system via the inhibitory effect on P450. These are effects that are not covered within any of the standardized TGs. At least for wildlife species, it is specifically pointed out in the OECD Guideline Document (OECD 2012, page 27), that EDs that damage the corticosteroid system will not be covered by the EATS-modalities. This demonstrates the importance of alternative studies besides the standardized OECD TGs to discover EDCs.

- Introducing an in vitro assay for the screening of ED effects on the corticosteroid system would be a possible way to expand the OECD $\mathrm{CF}$ at Level 2 beyond the present EATS-modalities.

Adverse effects on the motor activity of the exploratory behaviour in male mice were found in an earlier study by Tanaka (1993) that did not involve offspring. This earlier study does not correspond well to any of the OECD TGs for mammals. The duration of exposure was for 7 weeks which is longer than in TG 407 but shorter than in TG 408. Testing of behavioural endpoints are not usually included in any of the OECD TGs 407 or $408^{19}$.

In a more recent study on mice published by Tanaka in 2003, PBO were administered via food to $\mathrm{F}_{0}$ and $\mathrm{F}_{1}$ generation. The duration of exposure in the study was similar to OECD TG 415 and TG 426. Reproductive and neurobehavioral effects were evaluated which makes the study more similar to TG 426: Developmental neurotoxicity. Neurobehavioral

19 To the author's knowledge or from the information given in OECD GD 150 (page 327) 
effects on male offspring were found as indicated by depressed olfactory orientation and delayed surface righting.

- TG 426 is adequate for evaluation of PBO if functional and behavioural developmental parameters are included among the endpoints studied

The effect of PBO on mammalian pituitary was demonstrated in vivo by Okajima and Hertting (1986). The complete study was not available for comparison with OECD TGs. However, in TG 443 histopathological analysis of pituitary are suggested and this could further be complemented with analysis of corticotropin levels in order to expand the protocol outside the EATS-modalities ${ }^{20}$.

- PBO might have ED effects other than the EATS-modalities covered by the OECD CF.

- The inclusion of corticotropin measurement in animal experiments within the OECD CF might possibly facilitate the discovery of endocrine effects caused by Cytochrome P450 inhibitors

PBO induced vitellogenin in Daphnia magna and this is a clear sign of endocrine disruption but notably not of estrogenic character (Hannas et al. 2011). OECD TG 211 at Level 5 of the CF describes the use of Daphnia magna in a reproduction test. The endpoints studied in the standardized protocol include numbers of offspring and sex ratio in offspring. The biomarker Vitellogenin is not measured in the standardized TG 211. This is perhaps because, unlike in fish, estrogens appear to have little role in regulating vitellogenin in daphnids. Still, it could be of value to include vitellogenin measurement in the protocol. It seems that vitellogenin gene expression is negatively controlled by ecdysteroids in these animals (Hannas et al. 2011). Endocrine disruptors that elicit antiecdysteroidal (or ecdysteroidal activity for that matter) can be evaluated by measurement of vitellogenin in daphnids and this was clearly demonstrated in the study by Hannas et al.

- OECD TG 211 is in the present form not adequate for testing of PBO

- With the incorporation of vitellogenin as endpoint, OECD TG 211 would be adequate for testing of PBO

${ }^{20}$ The release of corticotropin might be regarded as a part of the normal Steroidogenesis included among the EATS. 
An avian reproduction study showed that PBO decreased eggshell thickness, number of eggs laid, hatchling body weight and food consumption (EPA RED 2006). These endpoints are relevant for endocrine disruption but the original study was not available in order to compare its compliance with the standardized Avian Reproduction Assay (TG 206). It is therefore not known what species of bird that was used or what dose levels.

- OECD TG 206 might possibly be adequate for testing of PBO

\section{PBO and the specificity of Cytochrome P450 inhibition}

An important key to the understanding of endocrine effects caused by PBO, and other compounds that interact with steroidogenesis by inhibition of cytochrome P450 enzymes, depends on the understanding of the specificity of the interaction with different enzymes of the CYP family. To illustrate this a few comments here follows:

PBO has inhibitory effects on cytochrome P450 enzymes as for example demonstrated by the inhibition of progesterone $6 \beta$-hydroxylase activity in vitro (Miranda 1998). In fish this enzymatic activity derives from CYP3A27. Does this mean that the same inhibition takes place in humans? The somewhat corresponding enzyme to CYP3A27 in fish is CYP3A4 in humans. The human version of the enzyme is important for enzymatic oxidative metabolism of both testosterone (Mäenpää et al. 1993) and progesterone (Yamazaki and Shimada 1997). In addition CYP3A4 can metabolize $50 \%$ of all drugs on the market today and it is probable that $\mathrm{PBO}$ has inhibitory effect on this enzyme (Moores et al. 2011). If PBO has inhibitory effects on human CYP3A4 this could lead to serious effects. This is why the specificity of the inhibition has to be investigated. For example, Triacetyloleandomycin inhibits CYP3A in mammals but not the corresponding CYP3A27 in trout (Miranda 1998).

The specificity of enzyme inhibition also has consequences for studies that involve other endpoints of a more general estrogenic or androgenic character. While the toxicological effect of inhibition of P450 cytochrome enzymes by PBO is well known, and is exploited in pesticides, the possible simultaneous endocrine effect is less investigated. Should an in vivo study with the aim to investigate endocrine effects of PBO focus on estogenic or androgenic endpoints? Well, in theory the inhibition of CYP3A4 in humans and other vertebrates could affect both androgenic and estrogenic steroidogenesis. Based on the theoretical pos- 
sible dual inhibitory function of PBO on both testosterone and progesterone metabolism it is difficult to predict if PBO is best evaluated by methods that study estrogenic effects or methods that study androgenic effects. The endocrine effects of PBO on insects was unpredictable (Hannas et al. 2011).

- A wide approach of testing, including possible effects on different hormones is necessary for testing of PBO

For substances that have inhibitory effects on P450 enzymes it is necessary to retrieve better information on species specificity for a better understanding of possible endocrine effects as a result of influence on steroidogenic enzymes. For example it is known that CYP17A1 is one of the key steroidogenic enzymes (Kiyosawa et al. 2009) and hepatic CYP17A1 is preferentially up regulated in mice (Kiyosawa 2008a) but not in rats (Kiyosawa 2008b) after the exposure of o,p'-DDT. This means that rat and mice are very different in their vulnerability to endocrine effect of DDT.

- For PBO and other P450 inhibitors it is necessary to retrieve experimental data from both mammalian and non-mammalian studies. This is important since the specificity of the inhibition means that results from one may not safely be extrapolated to the other

Kinetics also adds to the complexity of testing for the endocrine effects caused by PBO and other cytochrome P450 inhibitors. The effects of these chemicals are not easy to predict since they sometimes are biphasic; they both inhibit and induces enzymatic activity. PBO shows a rapid inhibition of Cytochrome P450 enzymes at first but this is then followed by a slow induction process (Hogson et al. 1998 in EPA 2000).

\subsection{Resorcinol}

\section{Weight of evidence and comments on the reviewed studies}

The categorization by Danish CEHOS (2012) of resorcinol as a Category 1 endocrine disruptor guarantees a strong weight of evidence. However, CEHOS pointed out the inconsistency in results from in vivo studies, probably referring to the review by Lynch (2002) where thyroid effects in studies with rat, mouse and rabbit is discussed. 
The reviewed studies demonstrate endocrine effects relevant for human concern.

The single reviewed non-mammalian study demonstrated endocrine effects relevant for ecotoxicological concern.

In vitro studies demonstrated that resorcinol inhibits thyroid peroxidase and also affects both aromatase activity and TH-dependent cell proliferation.

All publications from mammalian studies focused on the effect of resorcinol on thyroid gland and thyroid hormones. The route of exposure is very important for the outcome of toxicity testing with resorcinol. This is concluded in two different review articles (Lynch et al. 2002 and Welsch 2008). In one of Welsch's own studies (Welsch et al. 2008) resorcinol had effects on the thyroid gland of male rats but the effects were not considered as adverse. Lynch et al. (2002) concluded that anti-thyroid effects of resorcinol are demonstrated after continuous exposure through diet, in drinking water, by repeated dermal application or after subcutaneous injection of an oil-base vehicle. Welsch (2008) concluded that several studies with oral dosing, subcutaneous injection in aqueous solution, or high dose administration through gavage did not show thyroid gland toxicity of resorcinol. This is explained by the rapid metabolism of resorcinol that does not allow resorcinol concentrations in the systemic circulation to reach levels that can cause thyroid toxicity.

Only one non-mammalian study was found among the scientific publications on possible endocrine effects of resorcinol. This study showed that resorcinol has a thyroid disrupting effect on fish (Thienpont et al. 2011).

\section{Comparison with OECD CF methods}

Resorcinol has effects ${ }^{21}$ on the aromatase enzyme that catalyses the last steps of estrogen biosynthesis from androgens (Waring et al. 2012). Aromatase Assay (US EPA OPPTS 890.1200) is the most specific of the standardized in vitro methods that specifically measures CYP19 activity. Inhibition of the aromatase activity by resorcinol would probably be detected with the OECD TG 456 (H295R Steroidogenesis Assay) as would be demonstrated by a reduced production of estradiol. However, from such results it would not be possible to discern that CYP19 was the specific enzymatic activity that was altered by resorcinol. On the other hand, H295R Steroidogenesis Assay is capable of detecting induction of

21 The effect was most probably inhibtion of aromatase but this was not clearly stated in the publication by Waring. 
aromatase activity, while the aromatase assay is not (OECD GD 150 page 141).

- Both in vitro methods OECD TG 456 and the US EPA Aromatase Assay can identify endocrine effects of resorcinol

Ghisari et al. (2009) did not detect any effect of resorcinol when using the MCF-7 cell line assay. Cell proliferation test with MCF-7 cell line has not yet been validated and given a TG number. It is not certain that this proliferation assay will be fully included within the CF as these assays are not recommended by ICCVAM (2003). This is because cell proliferation can be mediated through pathways other than those involving transcriptional activation of estrogen responsive genes ${ }^{22}$. There are no cell lines that have been validated for use as a thyroid screen in a manner similar to the E-Screen for estrogen activity.

The T-screen assay has been suggested as a candidate method to be added to the CF (OECD no 178 2012). This is a novel in vitro method used for the detection of TR agonists and antagonists. With this method both Waring et al. (2012) and Ghisari et al. (2009) could demonstrate endocrine effects of resorcinol.

Transcriptional activation assay (TG 455) is an important, fast and cheap method for screening of estrogenic and androgenic compounds at Level 2 of the OECD CF. Estrogenic effects of EDCs are in many cases mediated through direct interaction with the ER. In contrast to this, there is little evidence that chemicals can bind directly to the TR and in that way cause thyroid or anti-thyroid like reactions (DeVito et al. 1999). To a certain extent the introduction of T-screen could improve the "tool box" of screening methods for possible thyroid endocrine disruptors at Level 2 of the OECD CF. This could compensate for the fact that the cheap assays, like TG 455 for estrogenic endocrine disruptors, are not available for screening of thyroid endocrine disruptors.

- Results from testing of resorcinol suggest that the novel T-screen is useful and could therefore be added into the OECD CF at Level 2.

A two-generation study with rats exposed to resorcinol by drinking water was conducted by Welsch et al. (2008). Although not stated in the original article, but in the review by Welsch (2008) this two-generation study was in accordance with OECD TG 416. The LOAEL in this study

22 However, ICCVAM will complete a review of MCF-7 validation studies in 2011, so additions to the GD on this subject may be made in the future. 
was $223 \mathrm{mg} / \mathrm{kg} / \mathrm{bw} / \mathrm{d}$ as evident from histopathological changes of thyroid in male parents. No effects on histopathology, thyroid weight or thyroid hormone levels were found in female parents or in offspring. Thyroid histopathology was the most sensitive endpoint in this study which is in coherence with the conclusion from a workshop held in 1997 (O’Conner et al. 1999).

- Thyroid histopathology is the most sensitive endpoint for OECD TG 416.

- For resorcinol, thyroid histopathological endpoints in the $\mathrm{F}_{1}$ generation in comparison to the same endpoint in parental generation, did not improve the sensitivity of the study.

Besides the study by Welsch et al. in 2008, the here reviewed publications on resorcinol exposure to rodents, were all performed long before the development of the OECD GD 150. For the sake of comparison they can all be regarded as repeated dose studies similar to the TG 407 or TG 408.

OECD has developed the "enhanced Test Guideline 407" (TG 407 at Level 4 in the OECD CF) where the endpoints T3, T4, TSH, thyroid weight and histopathology are studied to discover thyroid toxicity. Enhanced OECD TG 407 is well suited to detect chemicals that affect the thyroid gland. This is the conclusion from an extensive review by CoelhoPalermo Cunha and Ravenzwaay (2005) in which an in-depth literature survey was carried out considering several modes of action and generally accepted reference chemicals. The OECD TG 407 is a 28-day testing scheme with rat and the recommendations given for the enhanced protocol is to incorporate all of the following endpoints: determination of T3, T4 and TSH, thyroid weight, gross necropsy and histopathology of the thyroid gland. It is further stated by Coelho-Palermo Cunha and Ravenzwaay that the TG 407 is more sensitive than the pubertal assays ${ }^{23}$ currently being evaluated in the USA. Even more sensitivity could be accomplished in the TG 407 assay if some endpoints (thyroid follicular cell proliferation and serum TH levels) are measured after 2 weeks of exposure instead of 4 (O'Conner et al. 1999).

- The enhanced OECD TG 407 is recommended for evaluation of resorcinol

- The enhanced OECD TG 407 could be further improved by measuring some endpoints after 2 weeks of exposure

${ }^{23}$ E.g. Male PP Assay, US EPA OPPTS 890.1500 
In OECD TG 234 fish is exposed to the test chemical from newly fertilized egg until about 60 days post hatch and the main endpoint studied are vitellogenin and gonadal histology. The assay has been fully validated for Japanese medaka, zebrafish and stickleback. The test method presented by Thienpont et al. (2011), where zebrafish embryos were exposed to resorcinol for 3 days and the level intrafollicular thyroid hormone measured, seems to be very promising.

- The use of fish embryos in TG 234 could be further developed or complemented with a rapid screening method for thyroid hormone disruptors according to the method presented by Thienpont et al. (2011)

In the evaluation of resorcinol by the Danish Centre on Endocrine Disrupters (CEHOS 2012) further testing is proposed to confirm the adverse effects on the thyroid system observed in humans. The OECD method proposed for this is the TG 231 (Amphibian Metamorphosis Assay).

- TG 231 is relevant for evaluation of resorcinol 


\section{Conclusion}

The following conclusions are based on the reviewed published studies on the three characterized chemicals. The conclusions are not necessary valid for all chemicals of similar origin, use or physical character ${ }^{24}$.

\section{Diuron}

From the reviewed studies on diuron it can be concluded that:

- Diuron has endocrine disruptive effects that can be discovered both by mammalian and non-mammalian test methods within the OECD Conceptual Framework.

- It is necessary to retrieve experimental data from both mammalian and non-mammalian studies and also important to maintain a wide approach e.g. including both "estrogenic" and "androgenic" throughout these tests.

On the basis of previous experience it might be tempting, for simplicity, to exclude endpoints from an extensive Test Guideline protocol but this should not be done lightly. When results from mammalian OECD Test Guidelines indicate typically estrogenic/female effects this does not necessary mean that similar effects can be expected from nonmammalian Test Guidelines. As exemplified in the case of diuron, an "estrogenic/female" effect in a mammalian study does not exclude the possibility of an "androgenic/male" effect in a non-mammalian study 25 .

\footnotetext{
${ }^{24}$ E.g. diuron exemplifies how test assays may respond to pesticides but diuron does not represent a typical pesticide in any wider context.

25 In experiments with rat diuron had physiological effects on ovaries while in experiment with lizard diuron had physiological and hormonal effects on testis
} 
Among the reviewed studies on diuron positive results were reported from studies that were conducted in a way similar to standardized or proposed OECD Test Guidelines.

- Some assays within the OECD Conceptual Framework would probably safely identify the endocrine effects of diuron caused by EATS-modalities.

a) TG 416, TG 443, TG 407 and TG 408 for rodents

b) TG 234: Fish Sexual Development Test

- Some assays within the OECD Conceptual Framework are currently being developed and have very good potential to identify the endocrine effects of diuron. These test organisms were sensitive to low concentrations of diuron. The endocrine systems of these organisms are poorly investigated and it is not certain that the effects demonstrate EATS-modalities.

a) Mollusc Partial Lifecycle Assays, Level 4 at the OECD CF

b) Mollusc Full Lifecycle Assays, Level 5 at the OECD CF

c) TG for Mysid Lifecycle Test, Level 5 at the OECD CF

\section{Piperonyl butoxide}

From the reviewed studies on piperonyl butoxide (PBO) it can be concluded that:

- PBO has endocrine disruptive effects that to some extent can be discovered by the methods included in the OECD Conceptual Framework but PBO also has endocrine effects that can be missed out by these methods.

- The specific inhibitory effect of PBO on certain cytochrome 450 enzymes indicates that this type of endocrine effect can be very species specific. Experimental data from mammalian studies cannot safely be extrapolated to non-mammals and perhaps not even extrapolated between different mammals.

- A wide approach of testing, including possible effects on different hormones is necessary for testing of PBO. This is because PBO possibly have inhibitory effects on enzymes important for the regulation of both estrogens and androgens. 
Among the reviewed studies on piperonyl butoxide positive results were reported from studies that were conducted in a way similar to standardized or proposed OECD Test Guidelines.

- Some assays within the OECD Conceptual Framework (CF) would probably safely identify the endocrine effects of piperonyl butoxide caused by EATS-modalities.

a) TG 456 in vitro steroidogenesis method

b) TG 426 for rodents, if functional and behavioural endpoints are studied

c) TG 443: Extended One-generation Reproductive Toxicity Study for rodents, if histopathological analysis of pituitary are among the endpoints studied

d) TG 206: Avian Reproduction Assay

- Some assays within the OECD Conceptual Framework could possibly be improved by the addition of certain endpoints

a) Vitellogenin could be measured in TG 211 (Daphnia Reproduction Test) in order to discover compounds that have ecdysteroidal or antiecdysteroidal activity.

b) The inclusion of corticotropin measurement in animal experiments within the OECD CF might possibly facilitate the discovery of endocrine disruption caused by Cytochrome P450 inhibitors.

- If there is an agenda for the expansion of the OECD CF at Level 2 beyond the present EATS-modalities one of the reviewed studies presented an interesting in vitro assay for the screening of ED effects on the corticosteroid system. A pituitary tumour cell line can be used to study the steroidogenesis of corticosteroid hormone and the influence of EDCs that show inhibitory effects on cytochrome P459 enzymes. ${ }^{26}$

\section{Resorcinol}

From the reviewed studies on resorcinol it can be concluded that:

- Resorcinol has endocrine disruptive effects that can be discovered with in vitro methods or with mammalian in vivo test methods within the OECD Conceptual Framework.

${ }^{26}$ Luini and Axelrod (1985) 
- Histopathological investigations of the thyroid and measurement of TH and TSH are endpoints that have been added to several OECD TGs for rodents. This seems like an effective way to include the study of thyroid related effects into already existing standardized methods.

Among the reviewed studies on resorcinol positive results were reported from studies that were conducted in a way similar to standardized or proposed OECD Test Guidelines.

- Some assays within the OECD Conceptual Framework (CF) would probably safely identify the endocrine effects of resorcinol caused by EATS-modalities.
a) TG 456 in vitro Steroidogenesis method
b) US EPA in vitro Aromatase Assay
c) TG 416 and 443 for rodents
d) Enhanced OECD TG 407 for rodents
e) TG 231: Amphibian Metamorphosis Assay

- One of the assays within the OECD Conceptual Framework could possibly be improved.

a) TG 234: Fish Sexual Development Test could be developed or complemented with a rapid screening method for thyroid hormone disruptors according to the method presented by Thienpont et al. (2011).

b) The enhanced OECD TG 407 could be improved by measuring some endpoints after 2 weeks of exposure. It should be further investigated whether the whole 4 week study could safely be shortened to only 2 week to make it more cost-efficient.

- One assay is currently being developed or has been suggested for inclusion into the OECD Conceptual Framework. This method could probably safely identify the endocrine effects of resorcinol caused by EATS-modalities.

a) In vitro T-screen assay (OECD document no 178 2012) 


\section{References}

Akcha, F., Spagnol, C., Rouxel, J. (2012) Genotoxicity of diuron and glyphosate in oyster spermatozoa and embryos. Aquatic Toxicology 106- 107: 104- 113.

Arnott, D.G., Doniach, I. (1952) The effect of compounds allied to resorcinol upon the uptake of radioactive iodine (131I) by the thyroid of the rat. Biochem J. 1952 February; 50(4): 473-479.

Battaglia, C., Gogal, R., Zimmerman, K., Misra, H. (2010) Malathion, Lindane, and Piperonyl Butoxide, Individually or in Combined Mixtures, Induce Immunotoxicity via Apoptosis in Murine Splenocytes In Vitro. International Journal of Toxicology 29(2) 209-220.

Bauer, E.R., Meyer, H.H., Stahlschimdt-Allner, P., Sauerwein, H., (1998) Application of an androgen receptor assay for the characterisation of androgenic or antiandrogenic activity of various phenylurea herbicides and their derivatives. Analyst 123, 2485-2487.

Berthezene, F., Perrot, L., Munari, Y., and Ponsin, G. (1979). Effets multiples du resorcinol sur la fonctionthyroidienne [Multiple Effects of Resorcinol on Thyroid Function]. Ann. Endocrinol. (Paris). 40, 67-68.

Buisson, S., Bouchart, V., Guerlet, E., Malas, J., Costil, K. (2008). Level of contamination and impact of pesticides in cupped oyster, Crassostrea gigas, reared in shellfish production area in Normandy (France). J. Environ. Sci. Heal B 43:, 655-664.

Call, D. J., Brooke, L. T., Kent, R. J., Knuth, M. L., Poirier, S. H., Huot, J. M., Lima, A.R. (1987) Bromacil and diuron herbicides: Toxicity, uptake, and elimination in freshwater fish. Arch. Environ. Contam. Toxicol. 16: 607-613.

Campiche, S., Becker-van Slooten, K., Ridreau, C., Tarradellas, J. (2006) Effects of insect growth regulators on the nontarget soil arthropod Folsomia candida (Collembola). Ecotoxicology and Environmental Safety 63: 216-225.

Cardone, A., Comitato, R., Angelini, F. (2008) Spermatogenesis, epididymis morphology and plasma sex steroid secretion in the male lizard Podarcis sicula exposed to diuron. Environmental Research 108: 214-223.

CEHOS - Danish Centre on Endocrine Disrupters. (2012) Evaluation of 22 SIN List 2.0 substances according to the Danish proposal on criteria for endocrine disrupters. May 2012.

Chapman, G.A., Denton, D.L., Lazorcha, J.M., editors. (1995) Short-term methods for estimating the chronic toxicity of effluents and receiving waters to west coast marine and estuarine organisms. Washington DC: US Environmental Protection Agency. EPA/600/R-95-136. $661 \mathrm{p}$.

Cheymol, J., Gay, Y., and Laveden, J. P. (1951) Y A-tile une action antitthyroidiene des diphénols? C. R. Seanc. Soc. Biol. Fil. 145:999-1001.

Coelho-Palermo, G., van Ravenzwaay, B. (2005) Evaluation of mechanisms inducing thyroid toxicity and the ability of the enhanced OECD Test Guideline 407 to detect these changes. Arch. Toxicol. 79: 390-405. 
Cooksey, R. C., Gaitan, E., Lindsay, R. H., Hill, J. B., and Kelly, K. (1985) Humic substances, a possible source of environmental goitrogens. Org. Geochem. 8: 77-80.

Connat, J-L. (1988) Effects of Different Anti-Juvenile Hormone Agents on the Fecundity of the Female Cattle Tick Boophilus Microplus. Pesticide Biochemistry and physiology 30: 28-34.Danish Ministry of the Environment. (2011) Establishment of criteria for endocrine disruptors and options for regulation.

DeVito, M., Biegel, L., Brouwer, A., Brown, S., Brucker-Davis, F., Oliver Cheek, A., Christensen, R., Colborn, T., Cooke, P., Crissman, J., Crofton, K., Doerge, D., Gray, E., Hauser, P., Hurley, P., Kohn, M., Lazar, J., McMaster, S., McClain, M., McConnell, E, Meier, C., Miller, R., Tietge, J., Tyl, R. (1999) Screening methods for thyroid hormone disruptors. Workshop Summary. Environmental Health Perspectives, 107(5):407415).

Doniach, I., and Logothetopoulos, J. (1953). The goitrogenic action of resorcinol in rats. Br. J. Exp. Pathol. 34, 146-151.

EPA - National Pesticide Information Center. (2000) Techical Fact Sheet on Piperonyl Butoxide.

EPA OPP - Office of Pesticide Programs, Ecological Fate and Effects Division. Database available at http://www.ipmcenters.org/Ecotox/index.cfm

EPA RED (2006) Reregistration Eligibility Decision for Piperonyl Butoxide (PBO). List B Case No. 2525. EPA 738-R-06-005.

Fang, H., Tong, W., Perkins, R., Soto, A.M., Prechti, N.V. and Sheehan, D.M (2000) Quantitative comparisons of in vitro assays for estrogenic activities. Environ. Health Perspect. 108, 723-729.

Fernandes, G., Arena, A., Fernandez, C., Mercadante, A., Barbisan, L., Kempinas, W. (2007) Reproductive effects in male rats exposed to diuron. Reproductive Toxicology 23: 106-112.

Fernandes, G., Favareto, A., Fernandez, C., Bellentani, F., Arena, A., Grassi, T., Kempinas, W., Barbisan, F. (2012) Effects of Diuron on Male Rat Reproductive Organs: A Developmental and Postnatal Study. Journal of Toxicology and Environmental Health, Part A, 75:1059-1069.

Ghisari, M., Bonefeld-Jorgensen, E. (2009) Effects of plasticizers and their mixtures on estrogen receptor and thyroid hormone functions. Toxicology Letters 189: 6777.

Grassi, T., Trevisan Guerra, M., Perobelli, J., Choqueta de Toledo, F., Salioni da Silva, D., De Grava Kempinas, W. and Barbisan, L. (2011) Assessment of Female Reproductive Endpoints in Sprague-Dawley Rats Developmentally Exposed to Diuron: Potential Ovary Toxicity. Birth Defects Research (Part B) 92:478-486.

Hannas, B., Wang, Y.,Thomson, S., Kwon, G., Li, H., LeBlanc, G. (2011) Regulation and dysregulation of vitellogenin mRNA accumulation in daphnids (Daphnia magna) Aquatic Toxicology 101: 351-357.

Hecker,M., Hollert,H., Cooper,R., Vinggaard,A.M., Akahori,Y., Murphy,M., Nellemann,C., Higley,E., Newsted,J., Laskey,J., Buckalew,A., Grund,S., Maletz,S., Giesy,J., Timm,G. (2011). The OECD validation program of the H295R steroidogenesis assay: Phase 3. Final inter-laboratory validation study. Environ Sci Pollut Res 18:503-515.

Hinfray, N., Porcher, J-M., Brion, F. (2006) Inhibition of rainbow trout (Oncorhynchus mykiss) P450 aromatase activities in brain and ovarian microsomes by various environmental substances. Comparative Biochemistry and Physiology, Part C 144: 252-262. 
Hirashima, A., Takeya, R.,Taniguchi, E.,Eto, M. (1995) Metamorphosis, Activity of Juvenile-Hormone Esterase and Alteration of Ecdysteroid Titres: Effects of Larval Density and Various Stress on the Red Flour Beetle, Tribolium freemani Hinton (Coleoptera: Tenebrionidae) J. Insect Physiol. Vol. 41, No. 5, pp. 383-388.

Hodgson, E.; Levi, P. E. (1998). Interactions of Piperonyl Butoxide with Cytochrome P450. In Piperonyl Butoxide: The Insecticide Synergist; Jones, D. G.; Ed.; Academic: San Diego, CA, 1998; pp 41-53.

Horton, M.K., Rundle, A., Camann, D.E., Boyd Barr, D., Rauh, V.A., Whyatt, R.M. (2011) Impact of prenatal exposure to piperonyl butoxide and permethrin on 36-month neurodevelopment. Pediatrics 127 (3): e699-e706.

ICCVAM (2003). ICCVAM evaluation of in vitro test methods for detecting potential endocrine disruptors: estrogen receptor and androgen receptor binding and transcriptional activation assays. NIH Publication No: 03-4503.

Johri, A., Yadav, S., Singh, R.L., Dhawan, A., Ali, M., Parmar, D. (2006) Long lasting effects of prenatal exposure to deltamethrin on cerebral and hepatic cytochrome P450s and behavioral activity in rat offspring. European Journal of Pharmacology, 544:58-68.

Kang, H., Youn, Y., Hong, M., Kim, L. (2011) Antiproliferation and Redifferentiation in Thyroid Cancer Cell Lines by Polyphenol Phytochemicals. J Korean Med Sci 2011; 26: 893-899.

Kiyosawa, N., Kwekel, J.C., Burgoon, L.D., Dere, E., Williams, K.J., Tashiro, C., Chittim, B., Zacharewski, T.R. (2008a). Species-specific regulation of PXR/CAR/ER-target genes in the mouse and rat liver elicted by o,p'-DDT. BMC Genomics.9:487.

Kiyosawa, N., Kwekel, J.C., Burgoon, L.D., Williams, K.J., Tashiro, C., Chittim, B., Zacharewski, T.R. (2008b). o,p'-DDT elicts PXR/CAR-, not ER-, mediated responses in the immature ovariectomized rat liver. Toxicol. Sci. 101:350-363.

Klein, F., Ottis, V., and Velvart, J. (1950). Myxoedema from resorcinol ointment applied to leg ulcers. Lancet, Dec. 9, 768.

Kortenkamp, A., Martin, O., Faust, M., Evans, R., MacKinlay, R., Orton, F., Rosivatz, E (2011) State of the art assessment of endocrine disrupters. Project Contract Number 070307/2009/550687/SER/D3.

Krüger, T., Long, M., Bonefeld-Jørgensen, E. (2008) Plastic components affect the activation of the aryl hydrocarbon and the androgen receptor. Toxicology 246 : $112-123$

Lindsay, R.H., Hill, J.B., Gaitan, E., Cooksey, R.C., and Jolley, R.L. (1992) Antithyroid Effects of Coal- Derived Pollutants. Journal of Toxicology and Environmental Health 37, 467-481.

Lo, S., King, I., Alléra, A., Klingmüller, D., (2007) Effects of various pesticides on human 5alpha-reductase activity in prostate and LNCaP cells. Toxicol In Vitro. Apr; 21(3):502-8.

Luini, A.G., Axelrod, J. (1985) Inhibitors of the cytochrome P-450 enzymes block the secretagogue-induced release of corticotropin in mouse pituitary tumor cells. Proc Natl Acad Sci U S A. 1985 Feb;82(4):1012-4.

Luna-Acosta, A., Renault, T., Thomas-Guyon, H., Faury, N., b,c, Saulnier, D., Budzinski, H. (2012) Detection of early effects of a single herbicide (diuron) and a mix of herbicides and pharmaceuticals (diuron, isoproturon, ibuprofen) on immunological parameters of Pacific oyster (Crassostrea gigas) spat. Chemosphere 87: 1335-1340.

Lutz, I., Jie, Z., Opitz, R., Kloas, W., Ying, X., Menzel, R., Steinberg, C.E.W. (2005) Environmental signals: Synthetic humic substances act as xeno-estrogen and affect the thyroid system of Xenopus laevis. Chemosphere 61:1183-1188. 
Lynch, B., Delzell, E., Bechtel, D. (2002) Toxicology Review and Risk Assessment of Resorcinol: Thyroid Effects. Regulatory Toxicology and Pharmacology 36: 198-210.

Marco, F., Grazia Sacco, M., Roumengous, S., Collotta, A., Laura, G. (2012) Whole genome analysis in HepG2 cells exposed to diuron. Toxicology letters. Vol 211, suppl 17. S196.

Mirande, C.L., Hendeerson, M.C., Buhler, D.R. (1998) Evaluation of chemicals as inhibitors of trout cytochrome P450s. Toxocology and applied pharmacology 148, 237 244.

Matthiessen, P. (2008) An assessment of endocrine disruption in mollusks and the potential for developing internationally standardized mollusc life cycle test guidelines. Integrated Environmental Assessment and Management, vol 4: 274-284.

Moores, G., Alptekin, S., Field, L., Philippou, D. (2011) Interactions of piperonyl butoxide and its analogue with CYP3A4. Abstracts / Current Opinion in Biotechnology 22S, S15-S152, G23.

Mäenpää, J., Pelkonen, O., Cresteil, T., Rane. A. (1993) The role of cytochrome P450 3A (CYP3A) isoform(s) in oxidative metabolism of testosterone and benzphetamine in human adult and fetal liver. J Steroid Biochem Mol Biol. Jan;44(1):61-7.

National Toxicology Program (NTP) (1992) Toxicology and Carcinogenesis Studies of Resorcinol (CAS No. 108-46-3) in F344/N rats and B6C3F1 Mice (Gavage Studies), NTP Technical Report Series, No. 403. NTP, Research Triangle Park, NC.

Negri, A., Vollhardt, C., Humphrey, C., Heyward, A., Jones, R., Eaglesham, G., Fabricius, K. (2005) Effects of the herbicide diuron on the early life history stages of coral. Marine Pollution Bulletin 51: 370-383.

Noguerol, T-N., Boronat, S., Casado, M., Raldúa, D., Barceló, D., Piña, B. (2006) Evaluating the interactions of vertebrate receptors with persistent pollutants and antifouling pesticides using recombinant yeast assays. Anal Bioanal Chem 385: 10121019.

O'Connor, J. C., Frame, S.R., Davis, L.G., Cook, J.C (1999) Detection of thyroid toxicants in a Tier 1 screening battery and alterations in thyroid endpoints over 28 days of exposure. Toxicological Sciences 51: 54-70.

Okajima,T., Hertting, G. (1986) The possible involvement of cytochrome P-450 monooxygenase in AVP-induced ACTH secretion. Horm Metab Res. Apr;18(4):2812.

Orton, F., Lutz, I., Kloas, W., Routledge, E. (2009) Endocrine Disrupting Effects of Herbicides and Pentachlorophenol: In Vitro and in Vivo Evidence. Environ. Sci. Technol. 2009, 43, 2144-2150.

OECD (2006) Detailed review paper on thyroid hormone disruption assays. No 57. 2Aug-2006.

OECD (2012) OECD Guidance document on standardized test guidelines for evaluating chemicals for endocrine disruption. No. 150. ENV/JM/MONO(2012)22, 24-Aug2012.

OECD no 178 (2012) Detaild review paper on the state of the science on novel in vitro and in vivo screening and testing methods and endpoints for evaluating endocrine disruptors. Joint meeting of the chemicals committee and the working party on chemicals, pesticides and biotechnology. 21-Aug-2012.

Saglio, P., Trijasse, S. (1998) Behavioral Responses to Atrazine and Diuron in Goldfish. Arch. Environ. Contam. Toxicol. 35: 484-491.

Saito K, Isobe N, Kaneko H, Nakatsuka I (1999) In vitro studies for evaluating estrogenic and anti-estrogenic activities of resorcinol. Osaka, Sumitomo Chemical Company Ltd., Environmental Health Science Laboratory, pp. 1-16 (unpublished study). 
Samuel, K.C. (1955) Experimental production of goiter in rats. Lab. Invest. 4: 90-105. Seffner, W., Schiller, F., Heinze, R., Breng, R. (1995) Subchronic application of humic acids and associated compounds provokes histological changes of goitre in the rat. Exp. Toxicol. Pathol. 47: 63-70.

Takeuchi, S., Matsuda, T., Kobayashi, S., Takahashi, T., Kojima, H. (2006) In vitro screening of 200 pesticides for agonistic activity via mouse peroxisome proliferator-activated receptor (PPAR) $\alpha$ and PPAR $\gamma$ and quantitative analysis of in vivo induction pathway. Toxicology and Applied Pharmacology 217: 235-244.

Takeuchi, S., Iida, M., Yabushita, H., Matsuda, T., Kojima, H. (2008) In vitro screening for aryl hydrocarbon receptor agonistic activity in 200 pesticides using a highly sensitive reporter cell line, DR-EcoScreen cells, and in vivo mouse liver cytochrome P450-1A induction by propanil, diuron and linuron. Chemosphere 74:155-165.

Tanaka, T. (1992) Effects of piperonyl butoxide on F1 generation mice. Toxicology Letters vol. 60. 83-90.

Tanaka, T. (1993) Behavioural effects of piperonyl butoxide in male mice. Toxicology Letters, 69, 155-161.

Tanaka, T. (2003) Reproductive and neurobehavioural effects of piperonyl butoxide administered to mice in the diet.Food Addit Contam. Mar;20(3):207-14.

Teijon, G., Candela, L., Tamoh, K., Molina-Díaz, A., Fernández-Alba, A.R. (2010) Occurrence of emerging contaminants, priority substances $(2008 / 105 / C E)$ and heavy metals in treated wastewater and groundwater at Depurbaix facility (Barcelona, Spain). Science of the Total Environment, 408, 3584-3595.

Thibaut, R., Porte, C. (2004) Effects of endocrine disrupters on sex steroid synthesis and metabolism pathways in fish. Journal of Steroid Biochemistry \& Molecular Biology 92: 485-494.

Thienpont, B., Tingaud-Sequeira, A., Prats, E., Barata, C., Babin, P., Raldua, D. (2011) Zebrafish Eleutheroembryos Provide a Suitable Vertebrate Model for Screening Chemicals that Impair Thyroid Hormone Synthesis. Environ. Sci. Technol. 45: 7525-7532.

Turan, N., Waring, R.H., Ramsden, D.B. (2005) The effect of plasticisers on "sulphate supply" enzymes. Molecular and Cellular Endocrinology 244: 15-19.

Turner, L. (2003) Diuron Analysis of Risks to Endangered and Threatened Salmon and Steelhead. U.S. Environmental Protection Agency (EPA) Office of Pesticides (OPP) Environmental Field Branch.

Vinggaard, A.M., Hnida, C., Breinholt, V., Larsen, J.C. (2000) Screening of selected pesticides for inhibition of CYP19 aromatase activity in vitro. Toxicol In Vitro 14:227-234.

Waring, R. H., Ramsden, D. B., Jarratt, P. D. B., Harris, R. M. (2012) Biomarkers of endocrine disruption: cluster analysis of effects of plasticisers on Phase 1 and Phase 2 metabolism of steroids. International Journal of Andrology 35: 415-423.

Welsch, F. (2008) Routes and modes of administration of resorcinol and their relationship to potential manifestations of thyroid gland toxicity in animals and man. International Journal of Toxicology 27: 27-59.

Welsch, F., Nemec, M.D., and Lawrence, W.B. (2008) Two-generation reproductive toxicity study of resorcinol administered via drinking water to $\mathrm{Crl}$ : $\mathrm{CD}(\mathrm{SD})$ rats. International Journal of Toxicology 27: 43-57.

WHO (2002) Global assessment of the state-of-the-science of endocrine disruptors. Eds: Damstra, T., Barlow, S., Bergman, A., Kavlock, R. and Van der Kraak, G., WHO/PCS/EDC/02.2, World Health Organisation, Geneva. 180 pp. 
Yamazaki, H., Shimada, T. (1997) Progesterone and testosterone hydroxylation by cytochromes P450 2C19, 2C9, and 3A4 in human liver microsomes. Arch Biochem Biophys. Oct 1;346(1):161-9.

58 


\section{Sammanfattning på svenska}

För att kunna tillämpa rådande regelverk inom Reach och andra relevanta regelverk måste kemiska ämnen med hormonstörande egenskaper kunna identifieras. De testmetoder som är kopplade till lagstiftningen just nu (januari 2013) är inte framtagna specifikt för att mäta hormonstörande effekter. Därför pågår just nu ett arbete inom EU med att anpassa lagstiftningen och införliva standardiserade testmetoder för hormonstörande effekter. Internationellt validerade metoder för att testa hormonstörande effekter av kemikalier, samt även metoder som för närvarande håller på att tas fram, finns samlade i ett dokument från OECD: "Guidance Document on Standardized Test Guidelines for Evaluating Chemicals for Endocrine Disruption" (2012).

Syftet med den föreliggande studien var att utvärdera vilka metoder som använts vid utvärdering av hormonstörande effekter av kemikalier och att jämföra dessa med de föreslagna standardiserade metoderna i vägledningsdokumentet från OECD (2012). Vetenskapliga studier rörande hormonstörande effekter av tre stycken modellsubstanser har granskats:

- Diuron

- Piperonyl butoxide (PBO)

- Resorcinol

Utvärderingen visade att hormonstörande effekter från de granskade kemikalierna har påvisats i ett antal studier som i sitt genomförande är snarlika de standardiserade OECD metoder. Härav kan man dra slutsatsen att ett antal standardmetoder är effektiva för att påvisa hormonstörande effekter av de granskade modellsubstanserna.

- Hormonstörande effekter av diuron kan påvisas med standardiserade tester som använder sig av däggdjur och därmed har relevans för mänsklig hälsa. Hormonstörande effekter av diuron med relevans för påverkan på miljön kan påvisas med en standardiserad testmetod där utvecklingspåverkan på fisk studeras. 
- Hormonstörande effekter av piperonyl butoxide kan påvisas med standardiserat celltest samt med standardiserat test där äggskalsförtunning hos exponerade fåglar mäts. För att standardiserade testmetoder med däggdjur skall kunna påvisa hormonstörande effekter av PBO kan det krävas att man utvärderar försöksdjurens beteende eller histopatologiskt undersöker djurens hypofys. Effektmått av denna typ ingår normalt inte i standardprocedurer och därmed finns en risk att dessa hormonstörande effekter av PBO missas.

- Hormonstörande effekter av resorcinol kan påvisas med standardiserade celltest eller standardiserade test med däggdjur.

Utifrån den granskade litteraturen ges följande rekommendationer för att utveckla OECDs uppsättning av standardmetoder för hormonstörande effekter:

- Det finns bra metoder för att mäta påverkan på sköldkörtel hos däggdjur men testmetoder med relevans för effekter i miljön kan förbättras genom att mäta thyroidhormon i fiskembryos.

- Inga standardiserade metoder finns för att studera påverkan på hypfysen och korticotropinhormon. Det finns dock celltester som skulle kunna fungera som screeningmetoder för att identifiera kemikalier med sådana hormonstörande effekter.

- Biomarkören vitellogenin är välstuderad och används för att utvärdera östrogena effekter på fisk. Vitellogenin kan även mätas i standardiserat test med kräftdjur för att studera hormonstörande effekter som inte är kopplade till östrogen påverkan.

- Hormonell påverkan genom påverkan på cytochrome $\mathrm{P} 450$ behöver utforskas mera. Denna typ av påverkan kan vara väldigt specifik för vissa arter och därmed finns en risk att generella standardiserade tester missar dessa effekter.

Utifrån den granskade litteraturen kan ett antal generella slutsatser dras:

- Existerande standardmetoder för däggdjur har kompletterats med effektmått som rör påverkan på sköldkörtel. Detta verkar vara ett effektivt sätt att täcka in denna typ av hormonstörande effekter.

- Vid utvärdering av hormonstörande effekter är det viktigt att man bibehåller en bred ansats. Om inledande testresultat visar på typiska 
östrogena effkter är det ändå fullt möjligt att andra tester och testorganismer påvisare typiska androgena effekter.

- Det pågår en standardisering av tester med ryggradslösa djur. De granskade studierna visar att diuron har hormonstörande effekt på ryggradslösa djur redan vid mycket låg koncentration vilket bekräftar att sådana standardiserade tester har potential att utgöra ett mycket känsligt verktyg. 